\title{
Assessment of the Effectiveness of Different Safety Measures at Tunnel Lay-Bys and Portals to Protect Occupants in Passenger Cars
}

\author{
Ernst Tomasch *(D), Simon Franz Heindl (D), Gregor Gstrein (D), Wolfgang Sinz (D) and Hermann Steffan \\ Vehicle Safety Institute, Graz University of Technology, 8010 Graz, Austria; simon.heindl@tugraz.at (S.F.H.); \\ gregor.gstrein@tugraz.at (G.G.); wolfgang.sinz@tugraz.at (W.S.); h.steffan@tugraz.at (H.S.) \\ * Correspondence: ernst.tomasch@tugraz.at
}

check for updates

Citation: Tomasch, E.; Heindl, S.F.; Gstrein, G.; Sinz, W.; Steffan, H. Assessment of the Effectiveness of Different Safety Measures at Tunnel Lay-Bys and Portals to Protect Occupants in Passenger Cars. Infrastructures 2021, 6, 81. https:/ / doi.org/10.3390/infrastructures6060081

Academic Editor:

Pedro Arias-Sánchez

Received: 10 May 2021

Accepted: 19 May 2021

Published: 26 May 2021

Publisher's Note: MDPI stays neutral with regard to jurisdictional claims in published maps and institutional affiliations.

Copyright: (c) 2021 by the authors. Licensee MDPI, Basel, Switzerland. This article is an open access article distributed under the terms and conditions of the Creative Commons Attribution (CC BY) license (https:/ / creativecommons.org/licenses/by/ $4.0 /)$.
Abstract: Tunnel portals and tunnel lay-bys are hazardous spots for road users. Different infrastructure safety measures are in use, but the protection level is not known. In this study the following safety measures for reducing the injury risk are investigated: angular positioned $4 \mathrm{~m}$ and $8 \mathrm{~m}$ concrete barrier, crash cushion Alpina F1-50 and Alpina <prototype> crash cushion. A passenger car equipped with a data acquisition unit is accelerated to $100 \mathrm{~km} / \mathrm{h}$ and impacts the safety measure. The assessment of the latter is based on the EN 1317 criteria, specifically the Acceleration Severity Index (ASI), Theoretical Head Impact Velocity (THIV). Further assessment criteria are related to intrusions into the passenger compartment and post-crash motion. The best result in terms of ASI and THIV was achieved by the $8 \mathrm{~m}$ (ASI: 1.6, THIV: $30 \mathrm{~km} / \mathrm{h}$ ) concrete barrier. The crash cushion Alpina <prototype> showed good results for the ASI (1.8) but the THIV (57 km/h) was less satisfactory, while the angular positioned $4 \mathrm{~m}$ concrete barrier (ASI: 2.9, THIV: $53 \mathrm{~km} / \mathrm{h}$ ) and the crash cushion Alpina F1-50 (ASI: 3.3, THIV: $74 \mathrm{~km} / \mathrm{h}$ ) performed worst. Even though some of the measures showed good results, no protection measure tested currently complies with all the assessment criteria used.

Keywords: tunnel lay-by; tunnel portal; road restraint system; concrete barrier; crash cushion; run-off-road accident

\section{Introduction}

The EU-Directive 2004/54/EG defines minimum tunnel safety requirements to improve the accident situation in tunnels [1]. For new bi-directional tunnels exceeding a length of $1500 \mathrm{~m}$ with a traffic volume higher than 2000 vehicles per lane, lay-bys are mandatory if no emergency lane is present. In existing tunnels the feasibility and effectiveness of the implementation of lay-bys is to be evaluated. No design guideline for tunnel lay-bys and end-wall protection, however, is included in the directive. In cases where the end-wall of a tunnel lay-by or tunnel portal is not well designed in particular (Figure 1), these are critical spots on the road in the event of a vehicle collision. Vehicles are massively damaged and intrusions into the passenger compartment are very likely to take place (e.g. Kunc et al. [2]).

Austrian motorways and expressways currently have 132 tunnels with lengths greater than $200 \mathrm{~m} \mathrm{[3].} \mathrm{The} \mathrm{total} \mathrm{length} \mathrm{of} \mathrm{these} \mathrm{tunnels} \mathrm{is} 370 \mathrm{~km}$, which is $16.7 \%$ of the total length of motorways and expressways in Austria. The risk being fatally injured in a tunnel is 1.6 times higher than on motorways and expressways roads that are not enclosed [3]. These results are comparable with findings of other studies. The authors concluded that the risk of an accident in a tunnel is lower compared to the open road but the injury severity is significantly higher [4-8]. Specifically the risk being more severely injured is higher at the tunnel entrance compared to accidents inside the tunnel [4,6,9-14]. Although rear-end collisions are predominant inside the tunnel, single vehicle accidents are the most frequent accident type at the tunnel entrance $[4,6,11,14]$. In particular single vehicle accidents are 
most frequent in unidirectional tunnels [6]. In Austria, similar findings can be observed: Single vehicle accidents in unidirectional tunnels have a share of $61.8 \%$ at the portal and $26.3 \%$ in the tunnel [3]. On average, 30 persons in passenger cars are killed on motorways and expressways every year. One person is killed every year due to collisions at the tunnel portal or at the end-wall of a tunnel lay-by. Road user fatalities only count as fatal if the injured persons die within 30 days after the road accident [15].

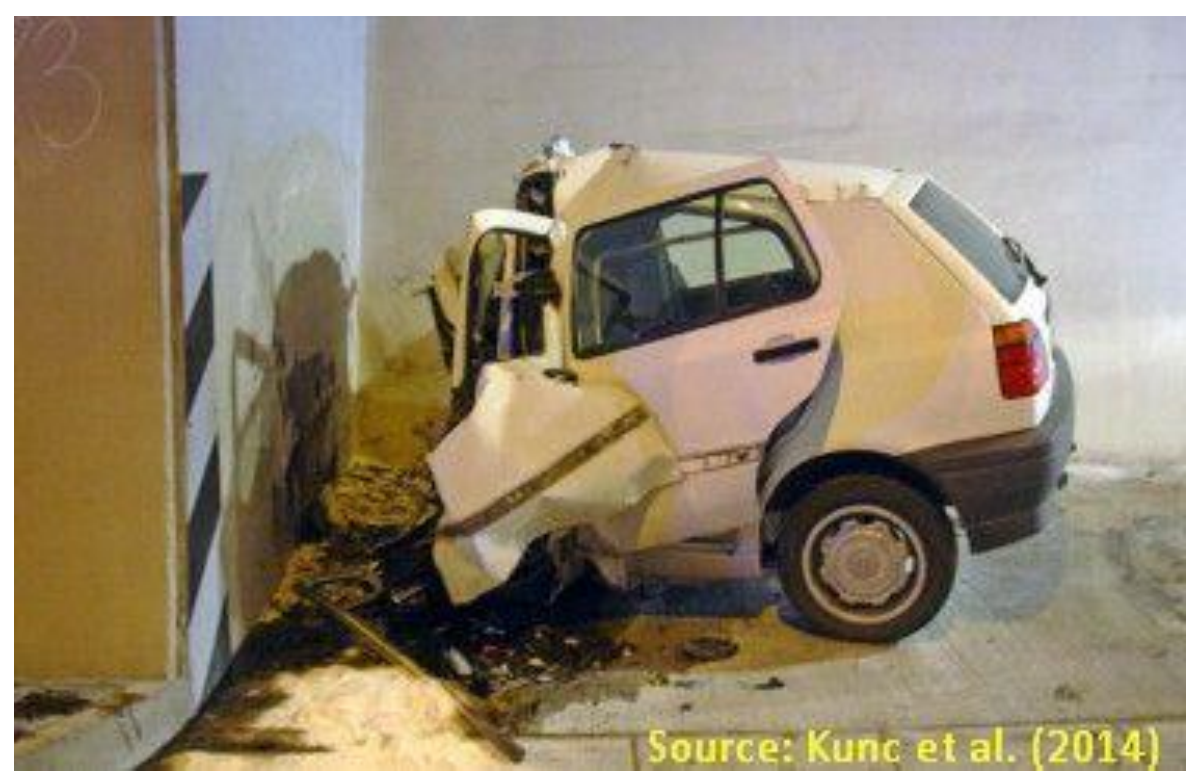

Figure 1. Tunnel accident at the end-wall of an unprotected tunnel lay-by (Source: Fire Brigade Koper in Kunc et al. [2]).

In Table 1 a detailed summary of road accidents in tunnels with a length of more than $200 \mathrm{~m}$ on motorways and expressways in Austria is given [3]. Even though the number of accidents has increased since 2012, the number of fatalities shows a decreasing tendency. Three road users were killed in tunnel accidents in the past five years. Further, Strnad and Schmied [3] analysed accidents in tunnels with a length of more than $500 \mathrm{~m}$ (Table 2). Between one and two road user fatalities were recorded on average in these tunnels in the period 2012 to 2016.

Table 1. Accidents in tunnels with a length of more than $200 \mathrm{~m}$ on motorways and expressways in Austria [3].

\begin{tabular}{cccc}
\hline Accident Year & Accidents & Injured Road Users & Fatalities \\
\hline 2002 & 95 & 156 & 13 \\
2003 & 93 & 154 & 4 \\
2004 & 133 & 231 & 6 \\
2005 & 112 & 201 & 7 \\
2006 & 69 & 128 & 4 \\
2007 & 96 & 180 & 3 \\
2008 & 84 & 155 & 6 \\
2009 & 60 & 121 & 7 \\
2010 & 75 & 108 & 4 \\
2011 & 48 & 80 & 5 \\
2012 & 110 & 168 & 7 \\
2013 & 99 & 173 & 3 \\
2014 & 105 & 167 & 3 \\
2015 & 110 & 163 & 1 \\
2016 & 137 & 213 & 3 \\
\hline
\end{tabular}


Table 2. Accidents in tunnels with a length of more than $500 \mathrm{~m}$ on motorways and expressways in Austria separated in bi-directional and unidirectional tunnels [3].

\begin{tabular}{|c|c|c|c|c|c|c|}
\hline \multirow[b]{2}{*}{ Accident Year } & \multicolumn{3}{|c|}{ Bi-Directional Tunnels } & \multicolumn{3}{|c|}{ Unidirectional Tunnels } \\
\hline & Accidents & $\begin{array}{l}\text { Injured Road } \\
\text { Users }\end{array}$ & Fatalities & Accidents & $\begin{array}{l}\text { Injured Road } \\
\text { Users }\end{array}$ & Fatalities \\
\hline 2006 & 14 & 20 & 3 & 54 & 106 & 1 \\
\hline 2007 & 20 & 51 & 0 & 71 & 119 & 3 \\
\hline 2008 & 23 & 49 & 0 & 56 & 99 & 6 \\
\hline 2009 & 27 & 74 & 4 & 27 & 39 & 2 \\
\hline 2010 & 18 & 27 & 0 & 40 & 56 & 3 \\
\hline 2011 & 13 & 29 & 4 & 29 & 41 & 1 \\
\hline 2012 & 28 & 56 & 4 & 78 & 105 & 2 \\
\hline 2013 & 24 & 45 & 2 & 71 & 123 & 1 \\
\hline 2014 & 12 & 21 & 2 & 82 & 120 & 1 \\
\hline 2015 & 11 & 19 & 1 & 83 & 121 & 0 \\
\hline 2016 & 14 & 41 & 0 & 113 & 158 & 1 \\
\hline
\end{tabular}

A new data collection methodology was introduced in 2012-the accident data management (UDM: Unfalldatenmanagement) [15]. The number of slightly and severely injured road users thus showed an enormous difference in 2012 compared to the previous years. It is assumed that the UDM data collection has been improved and the reported accidents are based on a level of recording accuracy, which in all probability was not equaled in previous years. The introduction of UDM had no influence on the reported fatal accidents.

Although the number of fatalities in tunnels is comparatively low, the Austrian Traffic Safety Programme 2011-2020 has introduced tunnel safety as a major priority issue [16]. Furthermore, ASFINAG the Austrian commercial operator and builder of motorways and expressways announced in its Traffic Safety Programme that tunnel safety would be a priority issue in 2020 [17].

Due to fire catastrophes in tunnels [18-20] caused by vehicle crashes [21] much attention was paid to fire accidents. Even though fire crashes are less frequent than traffic accidents the potential for a catastrophe is much higher in these cases $[5,20,22-27]$. Furthermore the geometry of tunnel lay-bys and tunnel portals received attention [18]. This especially because the end-wall of the tunnel lay-by was not protected with a safety measure. This leads to the following questions: 'What would be an appropriate design of the end-wall of a lay by or the tunnel portal'? 'Which safety measures are appropriate to reduce the injury severity in case of a collision'?

A number of safety measures are currently available at tunnel lay-bys and -portals (e.g. crash cushions, concrete barriers, guardrails, etc.) to protect occupants in passenger cars (examples are given in Figures $2-4$. However, only a small number of studies investigated the performance of safety measures for lay-bys and portals [2,28]. Kunc et al. [2,28] investigated the safety performance of a steel guardrail and a crash cushion (Figure $2 b$ ) and Figure 3b) at different impact angles. For the steel guardrails they analysed two different horizontal inclinations $\left(17^{\circ}\right.$ and $\left.35^{\circ}\right)$. The safety assessment was based on the Finite Element Method (FEM). The assessment was based on a comparison with impacts against an unprotected end-wall of the tunnel lay-by. Gabauer and Thompson [29] evaluated full scale crash tests from the National Highway Traffic Safety Administration (NHTSA) according to impact severity levels ASI and THIV of EN 1317-2 [30].

Studies on the performance of single elements of concrete barrier restraint systems (Figure 4) are not available. Furthermore there are no studies on the performance of steel guardrails or concrete barrier restraint systems that do not have the minimum installation length. To assess the impact severity level of road restraint systems (RRS), tests on restraint systems with a minimum installation length were evaluated [31-36]. Further studies used FEM or multi body simulations for the assessment of the injury level $[34,37]$ or used the physical tests for validation of the simulation models $[35,36,38,39]$. An average minimum 
installation length of steel guardrails is approximately $76 \mathrm{~m}$ (Standard Deviation (SD): 29) and concrete barriers have an average minimum installation length of approximately $82 \mathrm{~m}$ $(S D=29)$. These numbers are calculated from approximately 150 different RRS used in Austria [40].

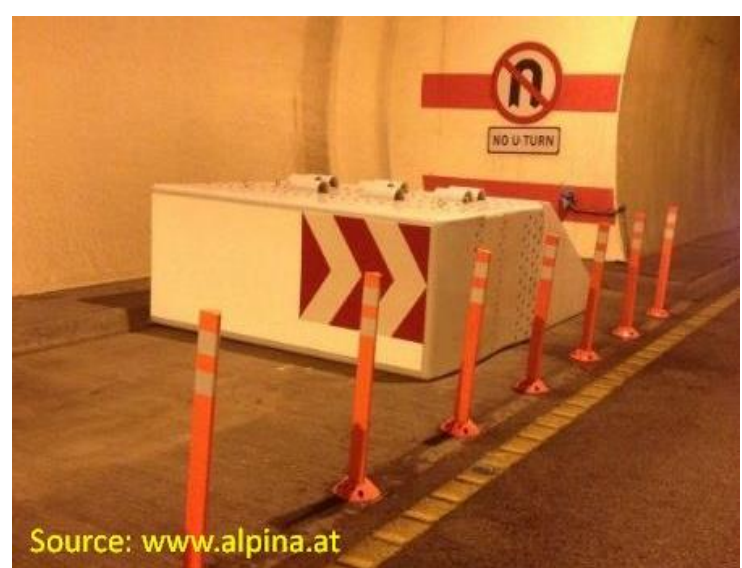

(a)

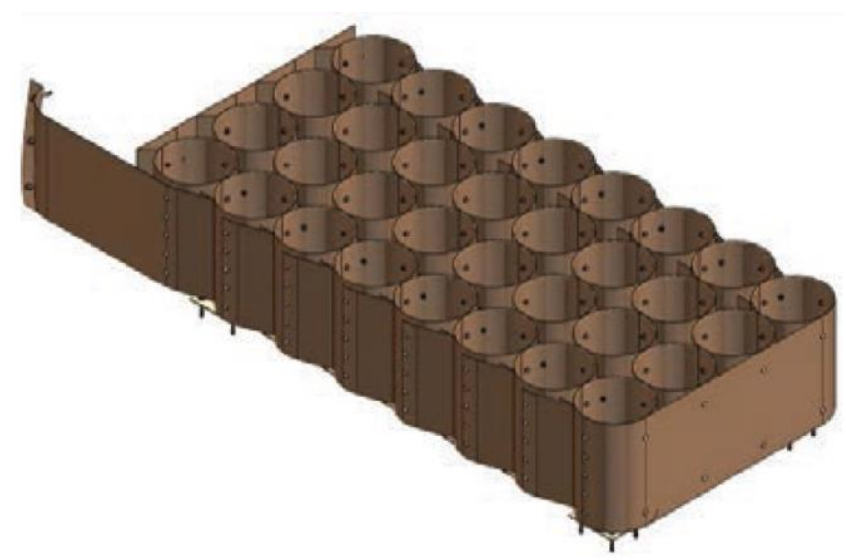

(b)

Figure 2. Crash cushion positioned in front of the end-wall of a lay-by (a) [42] and geometrical model a crash cushion (b) $[2,28]$.

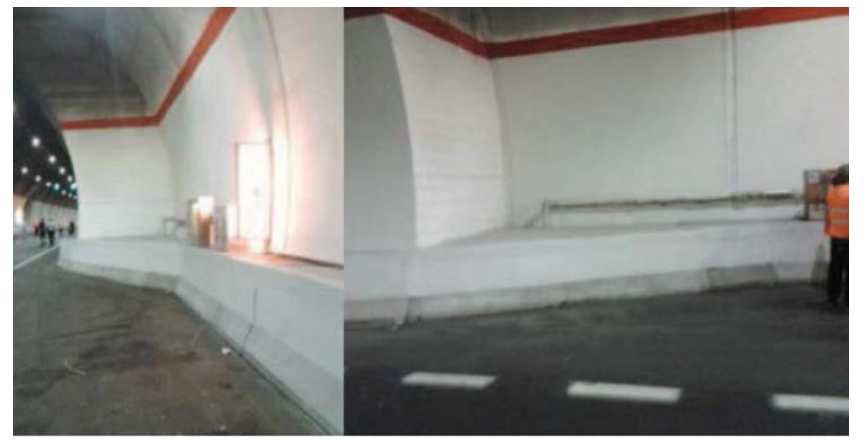

(a)

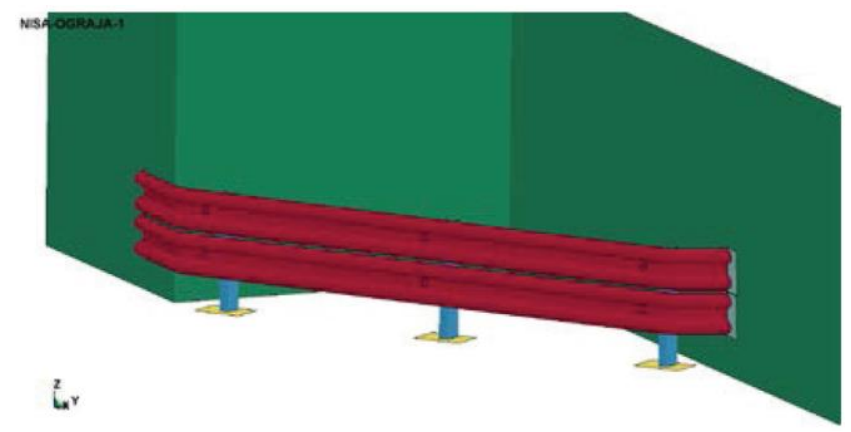

(b)

Figure 3. Protection measures of the tunnel lay-by end-wall. (a) protection of the edge of the end-wall with in-situ concrete (a) [41] or angled concrete barrier (b) $[2,28]$.

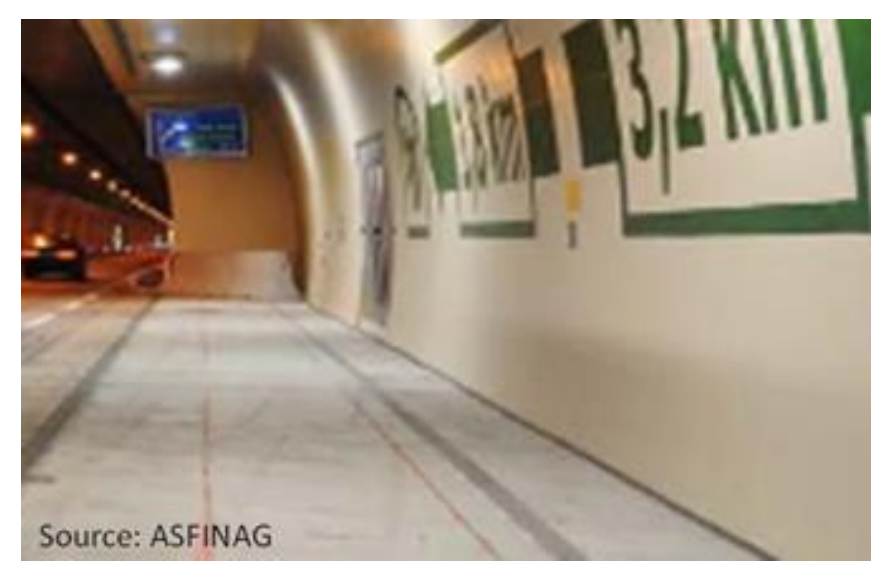

(a)

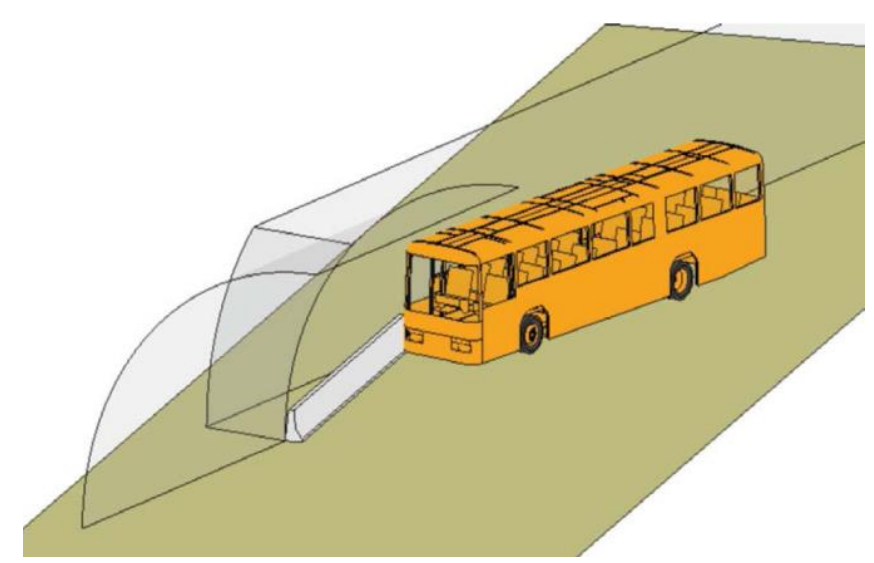

(b)

Figure 4. Tunnel lay-by protection measure. (a) angular positioned concrete barrier [43] and (b) crash cushion at the end-wall of the tunnel lay-by [41]. 
The safety level of in-situ concrete [41] to protect a vehicle colliding with the end-wall of a tunnel lay-by is not publicly available. However, in-situ concrete restraint systems [40] just meet the impact severity level "B" of EN 1317-2 [30] with a maximum allowed ASI of 1.4. It is expected that the protection of the tunnel lay-by end-wall with in-situ concrete would have a similar protection level.

Some countries (Spain, France, Italy, Slovenia) reported the use of angled barriers (steel or concrete) with different length or crash cushions to mitigate the consequences in case of a collision [41]. Steel guardrails and crash cushions are mounted to the tunnel wall or to the road. Concrete barriers are positioned in front of the end-wall of the tunnel lay-by. In Austrian tunnels, in particular, concrete barriers with a length of $4 \mathrm{~m}$ and crash cushions are predominantly used. For maintenance reasons (e.g., no damage of power supply connections beneath the road, quickly mounting and demounting of the crash cushion) it is required that crash cushions are not anchored to the road on Austrian motorways and expressways. With the regulations RVS 09.01.24 [44] and RVS 09.01.25 [45] launched 2014 and 2015 respectively the goal is to harmonize tunnel portal and tunnel lay-by design and guarantee the best possible protection in the event of an impact. No studies concerning the effectiveness of these measures (angular positioned concrete barriers, crash cushions not used for a speed limit), however, are currently available.

The objective of the present research project is to assess the safety effectiveness to protect occupants of passenger cars of different protection measures for tunnel lay-bys and portals for unidirectional tunnels with a speed limit of $100 \mathrm{~km} / \mathrm{h}$. The following safety measures that are not directly anchored to the road surface, are investigated:

- $\quad$ angular positioned $4 \mathrm{~m}$ concrete barrier (Figure 4),

- angular positioned $8 \mathrm{~m}$ concrete barrier (Figure 4),

- non-redirective crash cushion Alpina F1-50 not designed for this speed limit (Figure 2a),

- $\quad$ non-redirective crash cushion Alpina < prototype > not designed for this speed limit (Figure 2a).

The angular positioned $4 \mathrm{~m}$ concrete barrier is to be tested, because this safety measure is commonly used to avoid collisions with an unprotected end-wall of the tunnel lay-by. Subsequently the safety performance of an angular positioned concrete barrier with a length of $8 \mathrm{~m}$ should be tested. There is no detailed information on how often a crash cushion Alpina F1-50 is used at tunnel portals or lay-bys but a relatively large number of thesedevices are installed on motorways and expressways. Further an improved crash cushion labelled as <prototype $>$ is to be tested to assess if there is an improved protection determinable.

\section{Materials and Methods}

Figure 5 represents the flowchart of the methodology. In a first step an accident analysis of the Central Database for In-Depth Accident Studies (CEDATU) was performed to obtain the impact configurations in terms of run-off-road angle and impact angle. The impact speed was defined to correspond with the common speed limits in tunnels in Austria. The impact point and specifications for the test vehicles obtained from the EN 1317-1 [30,46] and EN 1317-3 [47]. Finally the assessment was carried out on the basis of the 1317-2 [30] and 1317-3 [47] criteria and conclusions and recommendations were drawn.

\subsection{Impact Configuration}

The tunnel lay-by is rebuild with concrete blocks which are anchored to the road surface (Figure 6). The width of the tunnel lay-by is $2.7 \mathrm{~m}$ according to the Austrian standard RVS 09.01.24 [44]. At the side of the test area concrete barriers were positioned to prevent the vehicle from leaving the test site.

The run-off-road angle is calculated based on real-world accidents of the CEDATU database [48,49]. A run-off-road angle is calculated on average as $5.4^{\circ}$ (SD: 4.1 ) with a run-off-road velocities of between $95 \mathrm{~km} / \mathrm{h}$ and $105 \mathrm{~km} / \mathrm{h}$. A maximum run-off-road angle of $16^{\circ}$ was observed. Based on theoretical considerations of Hoschopf and Tomasch [50] a 
maximum run-off-road angle at $100 \mathrm{~km} / \mathrm{h}$ run-off-road speed is calculated to $5.4^{\circ}$ at dry road (road friction $=0.7$ ) road conditions. For the tests the run-off-road angle is set to $5^{\circ}$.

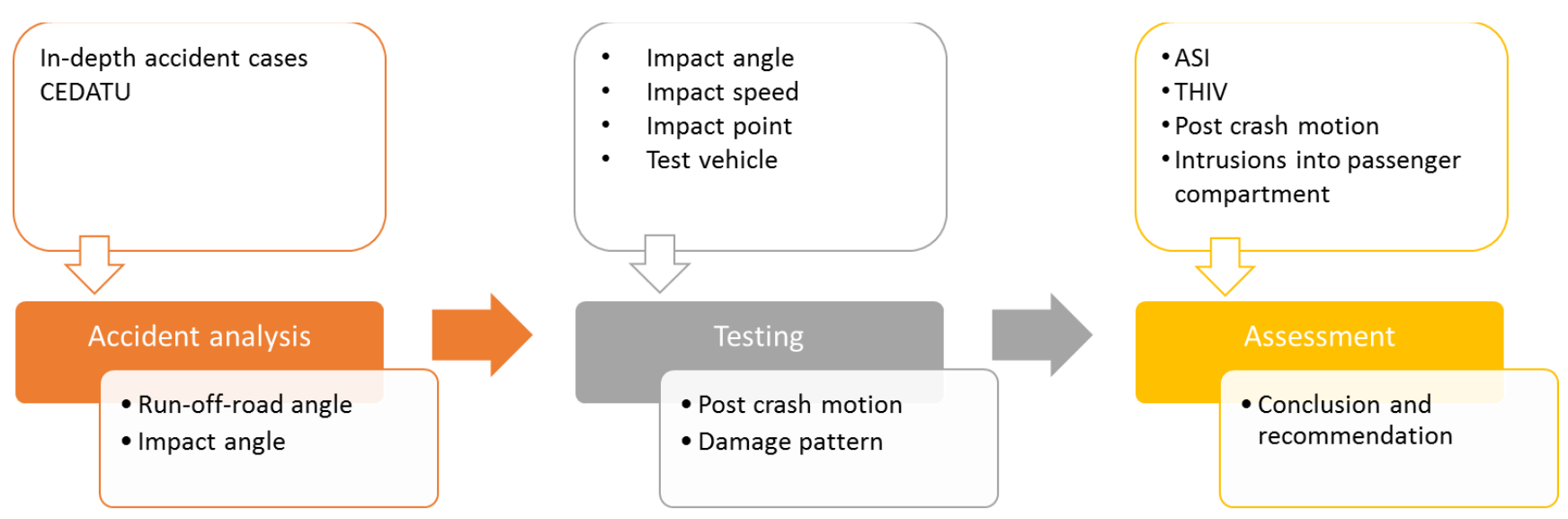

Figure 5. Flow chart of the Methodology.
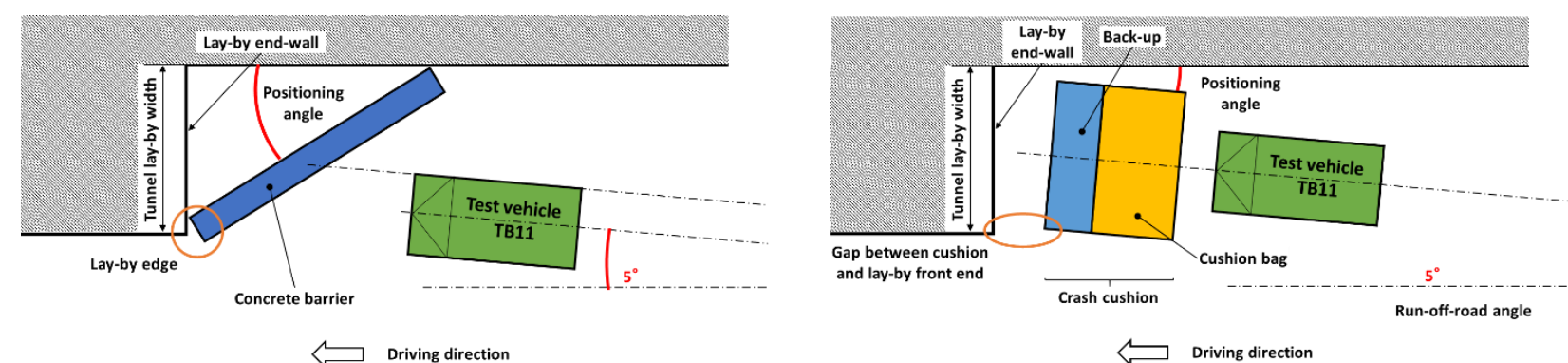

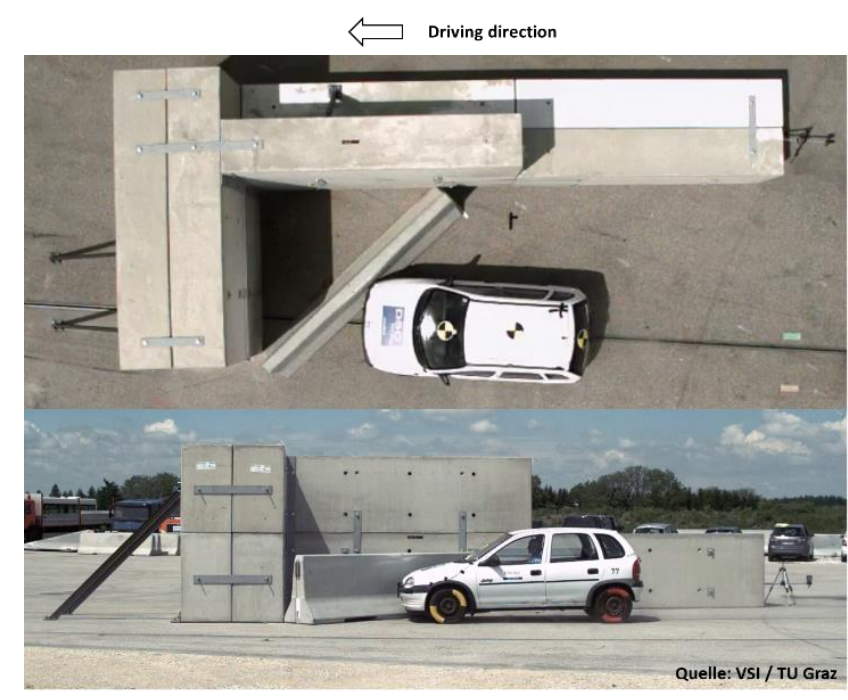

(a)

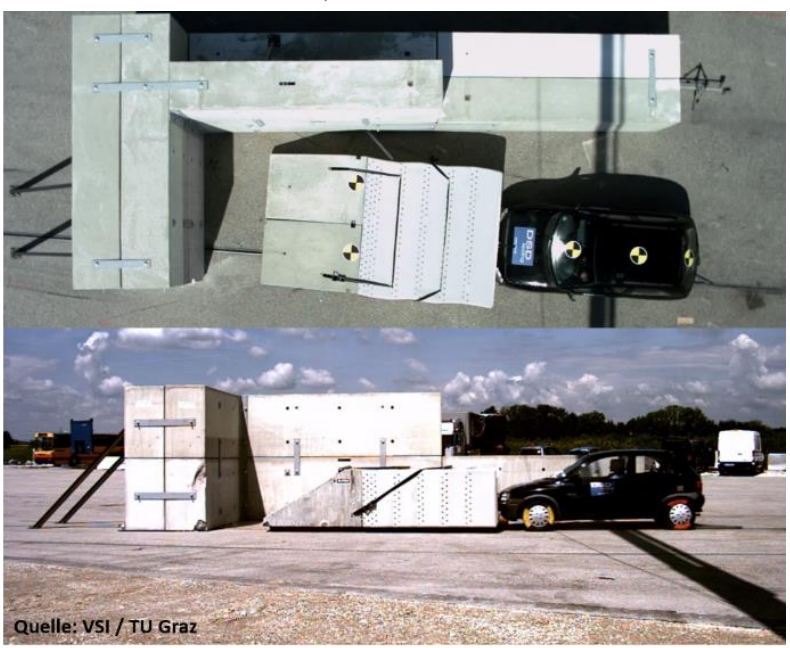

(b)

Figure 6. Test set-up for an angular positioned concrete barrier and vehicle position at first contact (a) and the crash cushion with the vehicle position at the first contact $(\mathbf{b})$.

The position of the concrete barrier is based on the length of the barrier and the width of the tunnel lay-by (Figure 6). For the $4 \mathrm{~m}$ barrier the positioning angle is $42^{\circ}$ and for the $8 \mathrm{~m}$ barrier $18^{\circ}$. The collision angle calculated from the positioning angle and the run-off-road angle is $47^{\circ}$ for the $4 \mathrm{~m}$ barrier and $23^{\circ}$ for the $8 \mathrm{~m}$ barrier. The positioning angle of the crash cushion is set at $5^{\circ}$ so that the vehicle impacts the crash cushion at an angle of $0^{\circ}$. The energy absorbing structure ("cushion bag") of the crash cushion is 
mounted to a triangular shaped concrete wall, which is termed the "back-up". The crash cushion is positioned approximately $1.0 \mathrm{~m}$ ahead of the end-wall of the tunnel lay-by.

The impact point is defined so that the right front corner of the vehicle impacts the middle point of the concrete barrier. The impact point for the crash cushion is at the centre line so that the vehicle impacts the crash cushion with a full frontal overlap.

The impact speed is set to $100 \mathrm{~km} / \mathrm{h}$ according to the speed limit of unidirectional tunnels. The speed is measured approximately $6 \mathrm{~m}$ before the vehicle impacted the concrete barrier or the crash cushion in accordance with the EN 1317-2 [30] and EN 1317-3 [47].

For the tests vehicles (here: Opel Corsa) the TB11 requirements (kerb mass of $825+/-40 \mathrm{~kg}$ ) of EN 1317-1 [46] are used.

An ATD (anthropomorphic test device) was placed on the driver's seat. The ATD represents a vehicle occupant in shape, size and mass to reproduce the dynamic behavior of an occupant during the crash. The mass of the ATD is $75 \mathrm{~kg}$.

\subsection{Test Specimen}

Concrete barriers from the company REBLOC were used as angular positioned safety measure. According to the product description [51] the concrete barriers have an $\mathrm{H} 2$ containment level, working with W5 and an impact severity level of " $\mathrm{B}$ " according to EN 1317-2 [30]. The barriers have a length of $4000 \mathrm{~mm}$ or $8000 \mathrm{~mm}$ respectively, a width of $640 \mathrm{~mm}$ and a height of $1000 \mathrm{~mm}$. The weight of the $4 \mathrm{~m}$ barrier is $3000 \mathrm{~kg}$ and $6000 \mathrm{~kg}$ for the $8 \mathrm{~m}$ barrier. The minimum installation length of a RRS with a barrier length of $4 \mathrm{~m}$ is $64 \mathrm{~m}$ and of $8 \mathrm{~m}$ is $104 \mathrm{~m}$.

Non-directive cushions from the company ALPINA were used as crash cushions. These retain but do not redirect vehicles. The first crash cushion used is an Alpina F1-50 with the performance level 50 according to EN 1317-3 [47]. The impact severity class is " $\mathrm{B}$ ". The crash cushion has a width of $2400 \mathrm{~mm}$, a length of $3.380 \mathrm{~mm}$ (cushion bag: $1580 \mathrm{~mm}$, back-up: $1800 \mathrm{~mm}$ ) and a height of $1000 \mathrm{~mm}$ [52]. The <prototype> crash cushion has the performance level 80 . The crash cushion is approximately $0.5 \mathrm{~m}$ longer than the crash cushion F1-50. No further information can be given.

For each protection measure one test is performed. The test matrix is given in Table 3 .

Table 3. Test matrix of the performed tests.

\begin{tabular}{cccc}
\hline & Vehicle & Impact Speed & Impact Angle \\
\hline Concrete barrier 4 m & TB11 & $100 \mathrm{~km} / \mathrm{h}$ & $47^{\circ}$ \\
Concrete barrier 8 m & TB11 & $100 \mathrm{~km} / \mathrm{h}$ & $23^{\circ}$ \\
Crash cushion Alpina F1-50 & TB11 & $100 \mathrm{~km} / \mathrm{h}$ & $0^{\circ}$ \\
Crash cushion Alpina <prototype $>$ & TB11 & $100 \mathrm{~km} / \mathrm{h}$ & $0^{\circ}$ \\
\hline
\end{tabular}

\subsection{Data Acquisition}

For the assessment, multiple accelerometers with different measurement ranges were used. One tri-axial transducer (manufacturer: ASC; type: 5411LN-100) was positioned close to the vehicle's centre of gravity. The measurement range of these transducers is $100 \mathrm{~g}$. Two further tri-axial transducers (manufacturer: Measurement Specialities; type: 1203-0500-10-240X) were positioned close to the vehicle's centre of gravity for redundancy reasons. The measurement range of these transducers is $500 \mathrm{~g}$. Further to this an angular velocity sensor (rate sensor) (manufacturer: IES; type: 3103-2400) was equipped close to the centre of gravity. The maximum range of the velocity sensor is $2400^{\circ} / \mathrm{s}$. All of the transducers were mounted on a metal plate, which was mounted to the vehicle's centre of gravity (Figure $7 \mathrm{~b}$ ). All the transducers were calibrated. The coordinate system of the vehicle was defined according to EN 1317-1 [46] (Figure 7b).

For data acquisition a K3700 Minidau®(Mini Data Acquisition Unit) from KayserThrede with a sampling rate of $10 \mathrm{kHz}$ was used. The measurement as synchronized with high-speed cameras to enable a analysis by a contact switch in the front of the test vehicle that starts the DAQ and simultaneously triggers a flash-light. 


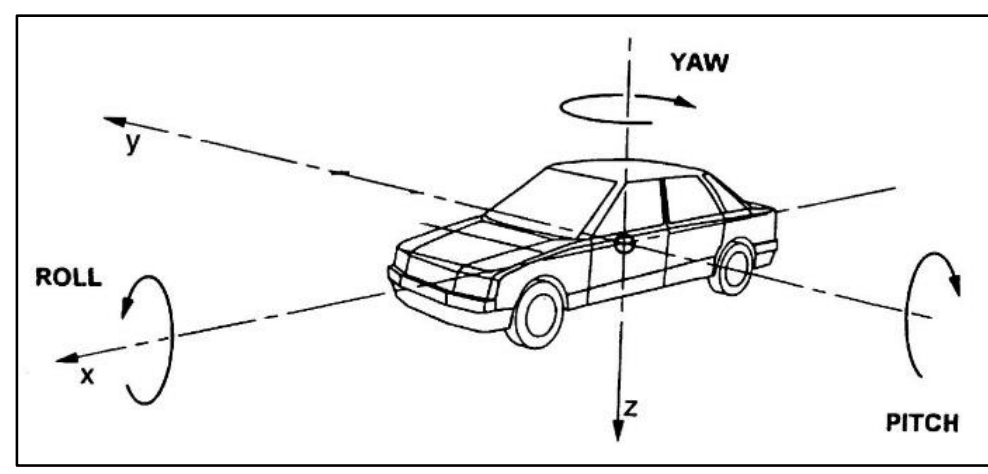

(a)

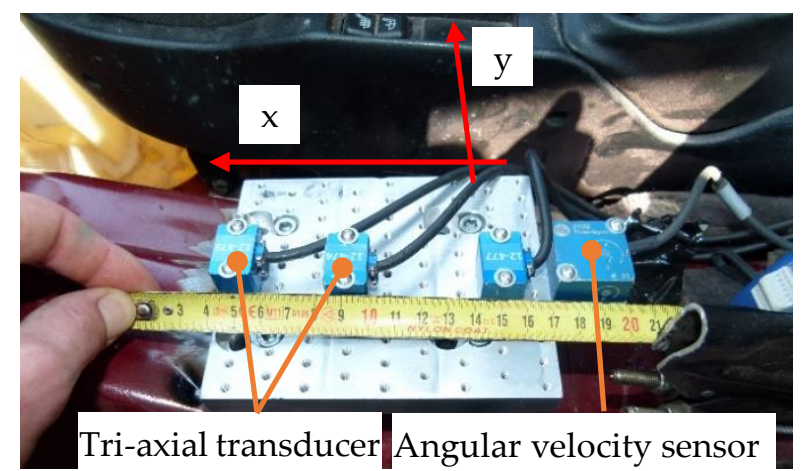

(b)

Figure 7. Vehicle coordinate system (a) and position of the acceleration transducers mounted at the center of gravity (b).

Three high speed cameras capture the vehicle motion at different positions. One panned camera was positioned perpendicular to the test object at the impact point i.e., to the path of the vehicle at normal speed. The high speed video cameras are operated with a rate of 500 frames per second. One high speed camera is positioned overhead to cover the vehicle motion at the impact point. One high speed camera is positioned at a point behind the impact in order to record vehicle roll and vertical lift. One high speed camera is positioned to capture the lateral motion.

\subsection{Assessment}

The assessment of the different safety measures is based on criteria defined in the EN 1317-2 [30] and EN 1317-3 [47]. Following criteria are assessed applicable to these tests: the severity indices ASI (Acceleration Severity Index) and THIV (Theoretical Head Impact Velocity).

$$
\begin{gathered}
A S I(k)=\left[\left(\frac{\bar{A}_{x}}{12}\right)^{2}+\left(\frac{\bar{A}_{y}}{9}\right)^{2}+\left(\frac{\bar{A}_{z}}{10}\right)^{2}\right]^{0.5} \\
T H I V=\left[V_{x}^{2}(T)+V_{y}^{2}(T)\right]^{0.5}
\end{gathered}
$$

The ASI is a function of acceleration and time and is intended to assess the severity of the vehicle motion for an occupant during an impact.

The THIV is used to assess the occupant impact severity in a vehicle in impacts with RRS. It is assumed that the head of the occupant is free to move. In the event of an impact the vehicle changes speed and motion direction, while the head of the occupant keeps to the pre-crash trajectory and continues moving until striking the interior of the vehicle. The magnitude of the velocity of the theoretical head impact is considered to be a measure of the vehicle-to-vehicle restraint system impact severity.

The limits of ASI and THIV are given in Table 4 (safety barriers) and Table 5 (crash cushions). Impact severity level " $\mathrm{A}$ " has a greater safety level for the occupants of an errant vehicle and impact severity " $B$ " has a greater safety level than " $C$ ". In Austria the minimum impact severity level " $B$ " is required [44].

Table 4. Impact severity limits of safety barriers according to EN 1317-2 [30].

\begin{tabular}{cccc}
\hline Impact Severity Level & \multicolumn{3}{c}{ Index Values } \\
\hline $\mathrm{A}$ & $A S I \leq 1.0$ & & \\
$\mathrm{~B}$ & $A S I \leq 1.4$ & and & $\mathrm{THIV} \leq 33 \mathrm{~km} / \mathrm{h}$ \\
$\mathrm{C}$ & $A S I \leq 1.9$ & & \\
\hline
\end{tabular}


Table 5. Impact severity limits of crash cushions according to EN 1317-3 [47].

\begin{tabular}{cccc}
\hline Impact Severity Level & Index Values \\
\hline A & $A S I \leq 1.0$ & and & THIV $\leq 44 \mathrm{~km} / \mathrm{h}^{1}$ \\
B & $A S I \leq 1.4$ & & \\
\hline
\end{tabular}

${ }^{1}$ value valid for frontal impacts.

Moreover, the behavior and deformation of the safety barrier or crash cushion as well as the test vehicle behavior and deformation are taken into account. The following assessment criteria are thereby evaluated:

After the impact the vehicle should be redirected without complete breakage of the elements of the restraint-system having occurred. No parts of the restraint system should penetrate the passenger compartment.

The test vehicle should remain upright during and after the impact. Moderate rolling, pitching and yawing are acceptable. The post-crash motion of the vehicle should be controlled.

Deformation of the passenger compartment or intrusions into the passenger compartment are not permitted.

\section{Results}

\subsection{Concrete Barrier $4 \mathrm{~m}$}

The top of the concrete barrier had a contact with the end-wall of the tunnel lay-by due to the impact. This is disadvantageous for the vehicle kinematics in terms of supporting the vehicle lift up. After the impact the vehicle was redirected according to the positioning angle of the barrier. The vehicle was lifted up and rotated approximately $90^{\circ}$ counter clockwise to its own longitudinal axis. At the side of the test area concrete barriers were positioned to prevent the vehicle from leaving the test site. The vehicle impacted these concrete barriers with its roof upside-down. The maximum distance of the vehicle to the road surface during the flight phase is roughly $1.4 \mathrm{~m}$ (Figure 8 ). The flight distance after the impact to the safety fence is approximately $14 \mathrm{~m}$. The right A-pillar and the header rail are damaged and passenger compartment intrusions were observed. The acceleration index ASI was calculated to 2.9 and THIV is calculated to $53 \mathrm{~km} / \mathrm{h}$. The change of velocity (delta-v) is $43 \mathrm{~km} / \mathrm{h}$. The post-crash speed was approximately $57 \mathrm{~km} / \mathrm{h}$.

\subsection{Concrete Barrier $8 m$}

After the impact, the vehicle was lifted from the road surface and had a flight height of approximately $0.5 \mathrm{~m}$ (Figure 9). The vehicle had a high pitching angle and the rear wheels had a maximum height of approximately $1.0 \mathrm{~m}$. The flight distance of the vehicle was approximately $10 \mathrm{~m}$. In the rollout phase, the vehicle impacted the concrete barriers positioned to prevent the vehicle to leave the test site with the front of the vehicle. No intrusions into the passenger compartment were observed. The ASI is calculated to 1.6 and THIV is calculated to $30 \mathrm{~km} / \mathrm{h}$. The change of velocity is $22 \mathrm{~km} / \mathrm{h}$ resulting in a speed after the impact of approximately $78 \mathrm{~km} / \mathrm{h}$.

\subsection{Crash Cushion Alpina F1-50}

The vehicle $\mathrm{w}$ fully decelerated (Figure 10). At the time when the vehicle stopped the crash cushion was pushed forward into the end-wall of the tunnel lay-by. Simultaneously the vehicle started to accelerate against the pre-crash motion direction due to the elastic restitution of the vehicle and the crash cushion. The final rest position was approximately $0.4 \mathrm{~m}$ in front of the damaged crash cushion. During the impact the wheels were lifted approximately $0.5 \mathrm{~m}$ above the road surface. 

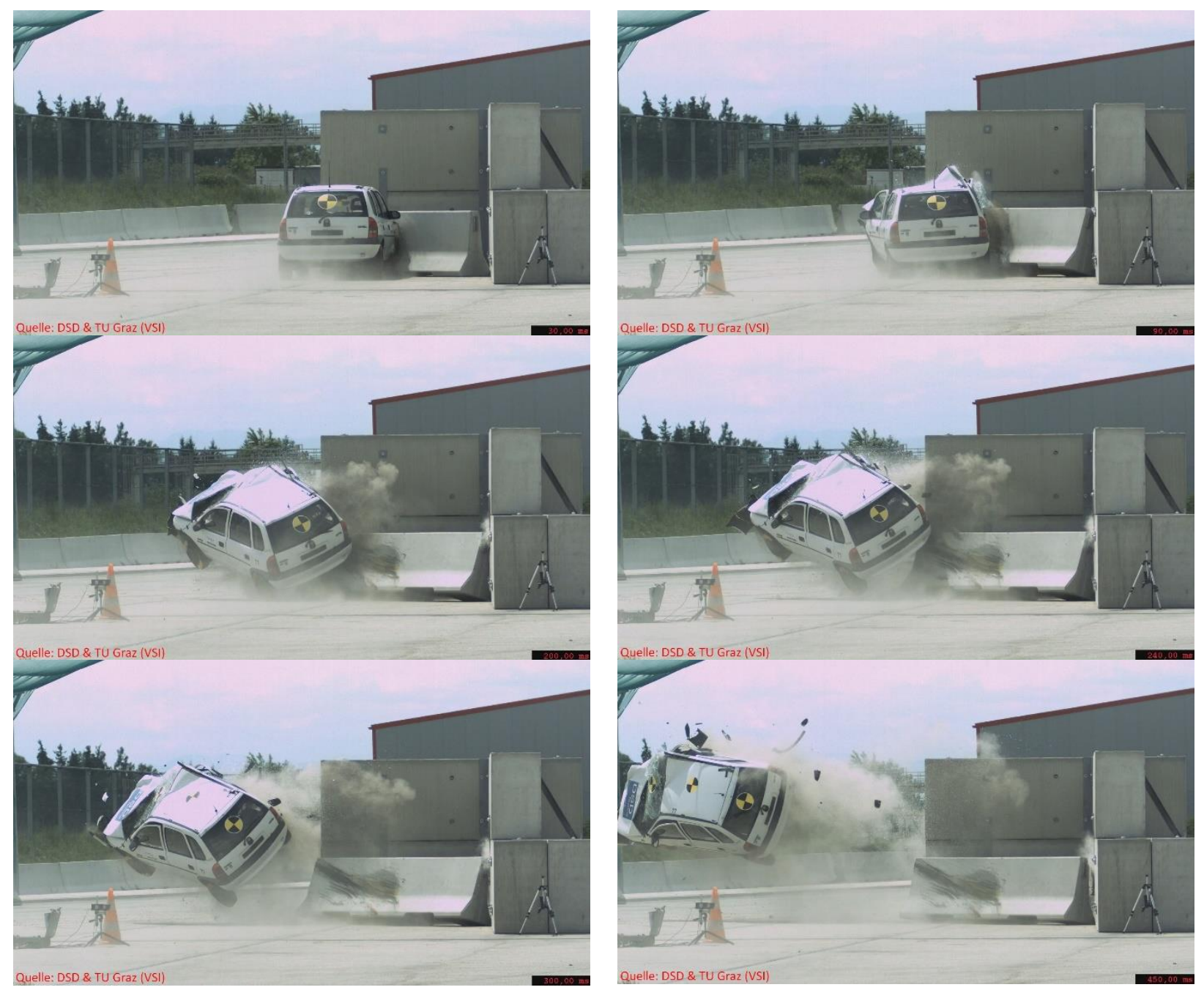

Figure 8. Vehicle motion impacting a $4 \mathrm{~m}$ concrete barrier. The vehicle impacts the barrier, lifts up and is rotating counter clockwise to its own longitudinal axis and redirected into the road lane.

The crash cushion was deformed up to its full energy absorption capability. The vehicle was damaged up to the front wheels and the wheels were displaced to the sill. The facia panel was pushed into the passenger compartment. The left and the right A-pillar were damaged and the header were rails slightly buckled. The bonnet was pushed back and the windscreen was smashed. The driver seat rails were destroyed and the seat including the dummy was projected forward against the facia panel. The ASI is calculated to 3.3 and THIV is calculated to $74 \mathrm{~km} / \mathrm{h}$.

\subsection{Crash Cushion Alpina <prototype>}

Within the test the vehicle was fully decelerated (Figure 11). After the vehicle came to a stop, the crash cushion was thrust against the tunnel lay-by. From this point in time the vehicle moved backwards and the final position reached was at $0.6 \mathrm{~m}$ in front of the crash cushion. No lift of the rear wheels was observed.

The crash cushion was deformed up to its full energy absorption capability and the front of the vehicle was damaged. No contact of the wheels with the sill was observed. No intrusions into the passenger compartment were observed. The ASI is calculated at 1.8 and THIV is calculated at $57 \mathrm{~km} / \mathrm{h}$.

\subsection{Summary of the Test Results}

A summary of the results of the tests is given in Table 6. 

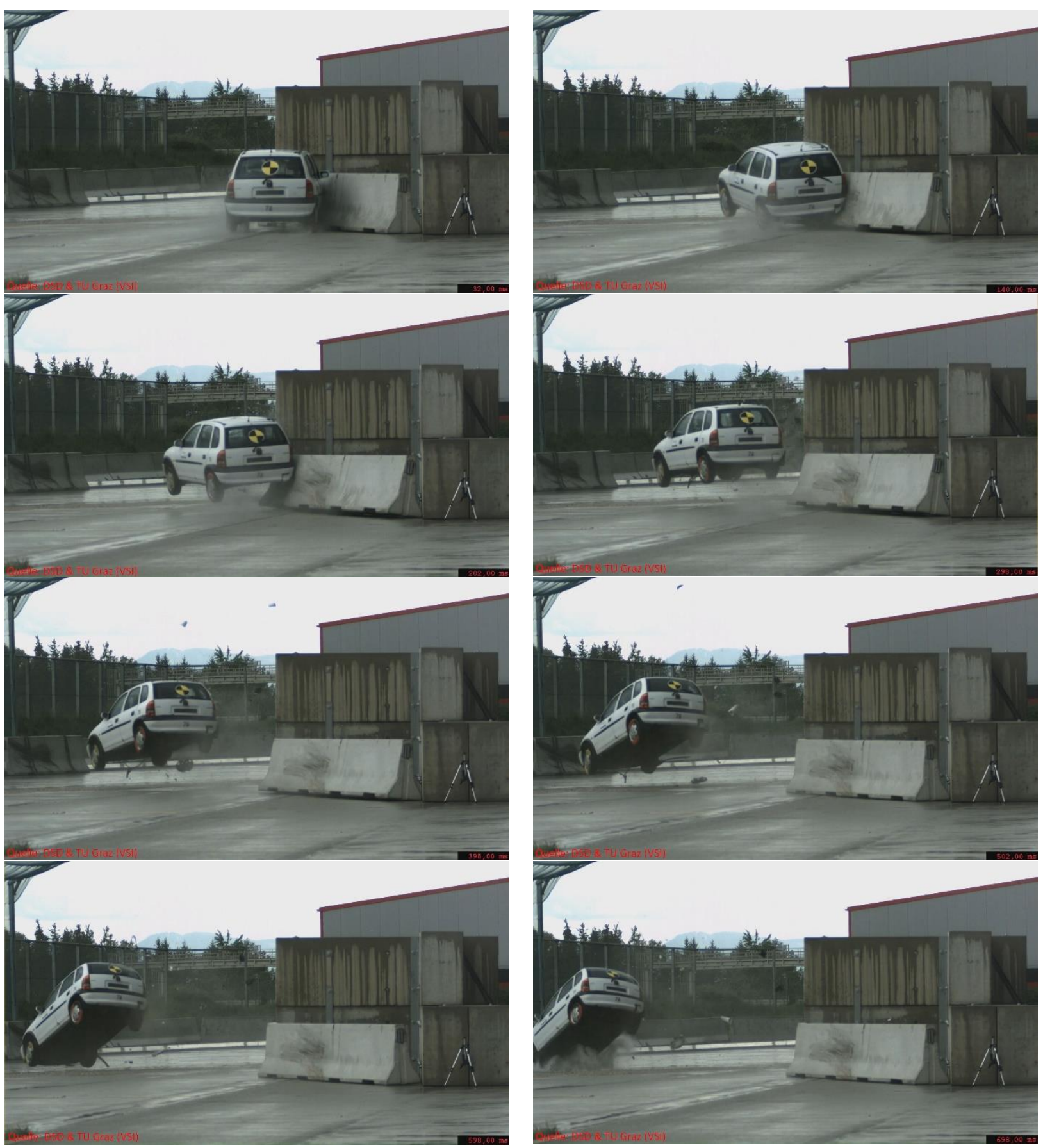

Figure 9. Vehicle motion impacting a $8 \mathrm{~m}$ concrete barrier. The vehicle impacted the barrier and was deflected upwards. The vehicle was rotated to the $y$-axis (pitching) and the rear wheels had a height of approximately $1.0 \mathrm{~m}$. 


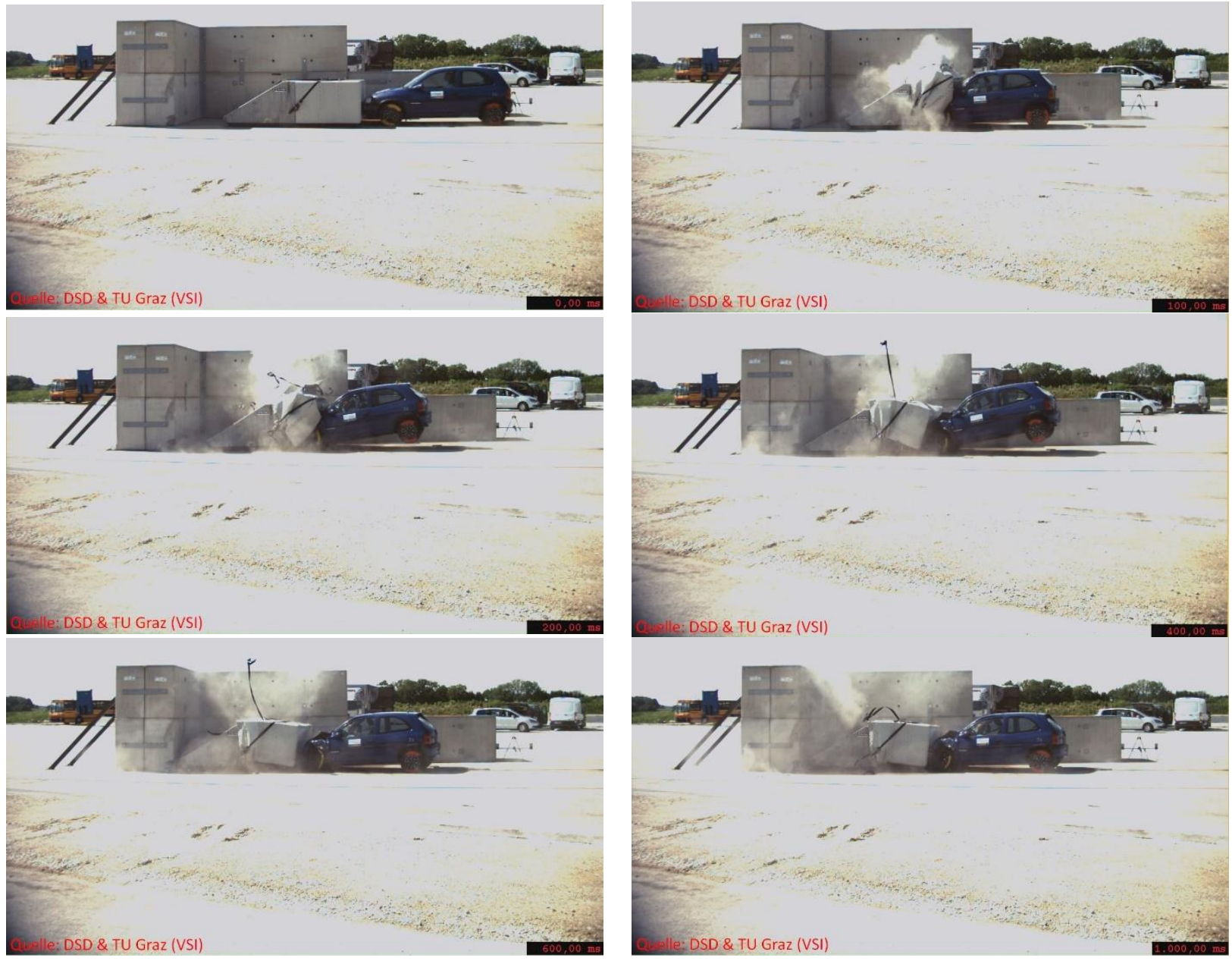

Figure 10. Vehicle motion impacting the crash cushion Alpina F1-50. The vehicle was fully decelerated and moved backwards due to the elastic restitution. The final position was approximately $0.4 \mathrm{~m}$ in front of the damaged crash cushion.

Table 6. Summary of the results of the assessment of the safety measures.

\begin{tabular}{|c|c|c|c|c|}
\hline & Barrier $4 \mathrm{~m}$ & Barrier $8 \mathrm{~m}$ & $\begin{array}{c}\text { Crash Cushion } \\
\text { F1-50 }\end{array}$ & $\begin{array}{c}\text { Crash Cushion } \\
<\text { prototype }>\end{array}$ \\
\hline $\begin{array}{l}\text { ASI (Limit for severity } \\
\text { level "B": } 1.4 \text { ) }\end{array}$ & 2.9 & 1.6 & 3.3 & 1.8 \\
\hline $\begin{array}{l}\text { THIV (Limit a: } \\
33 \mathrm{~km} / \mathrm{h} \text { for safety }\end{array}$ & & & & \\
\hline $\begin{array}{c}\text { barriers and b: } \\
44 \mathrm{~km} / \mathrm{h} \text { for } \\
\text { crash cushions) }\end{array}$ & 53 & 30 & 74 & 57 \\
\hline Secondary impact & $\begin{array}{l}\text { Vehicle lifts up and } \\
\text { impacts the end-wall of } \\
\text { tunnel lay-by }\end{array}$ & Vehicle lifts up & No secondary impact & No secondary impact \\
\hline Post crash kinematics & $\begin{array}{l}\text { Vehicle rotates and is } \\
\text { redirected into the road } \\
\text { lane and impacts left } \\
\text { tunnel wall }\end{array}$ & $\begin{array}{l}\text { No vehicle rotation but } \\
\text { is redirected into the } \\
\text { road lane and impacts } \\
\text { left tunnel wall }\end{array}$ & $\begin{array}{c}\text { Vehicle moved } \\
\text { backwards and was } \\
\text { rotating around the } \\
\text { vertical axis }\end{array}$ & $\begin{array}{c}\text { Vehicle moved } \\
\text { backwards and was } \\
\text { rotating around the } \\
\text { vertical axis }\end{array}$ \\
\hline $\begin{array}{l}\text { Test vehicle behavior } \\
\text { after the impact }\end{array}$ & Uncontrolled & Uncontrolled & Yawing & Yawing \\
\hline $\begin{array}{l}\text { Test vehicle } \\
\text { deformation }\end{array}$ & Intrusions & No intrusions & Intrusions & No intrusions \\
\hline
\end{tabular}



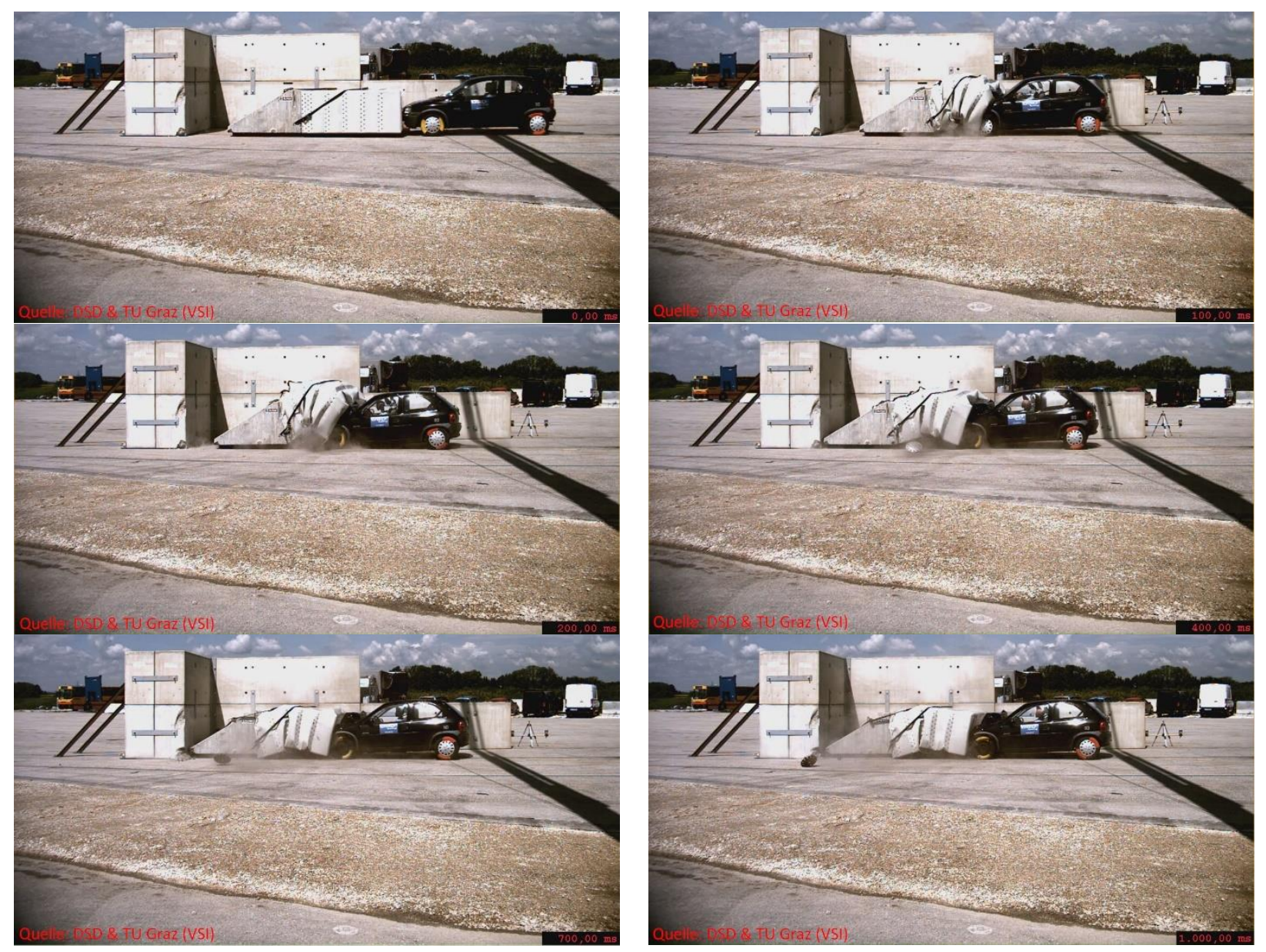

Figure 11. Vehicle motion impacting the crash cushion Alpina < prototype $>$. The vehicle was fully decelerated and moved backwards due to the elastic restitution. The final position was approximately $0.6 \mathrm{~m}$ in front of the damaged crash cushion.

\section{Discussion}

After the impact with the $4 \mathrm{~m}$ concrete barrier the vehicle is deflected upwards and a secondary impact with the end-wall of the lay-by could occur as a result. When this does not occur, however, the vehicle is redirected into the road lane with an angle corresponding to the positioning angle of the concrete barrier. A secondary collision with the tunnel wall on the left road lane will occur or the redirected vehicle might hit another road user. The change of velocity at the primary impact is approximately $43 \mathrm{~km} / \mathrm{h}$ and the secondary impact at the left tunnel wall would be at approximately $60 \mathrm{~km} / \mathrm{h}$. After the impact the vehicle rolled counter clockwise with a relatively high flight height and at the secondary impact the occupants were out of position. Airbags might be already triggered at the primary impact and would thus have no protective function at the secondary impact. The safety belt also only provides optimal occupant protection if both airbag and safety belt are still operational in a coordinated manner and when the vehicle is in an upright position. According to the EN 1317-2 [30] requirements a moderate rolling only is acceptable and the post-crash motion can then be controlled. At the impact with the $4 \mathrm{~m}$ concrete barrier, neither a moderate rolling, nor a controlled post-crash motion were observed.

Intrusions into the passenger compartment are not permitted. However, the right A-pillar was damaged and intrusions via the dashboard are observed and would as a result presumably have resulted in severe injuries in real accidents.

Although the vehicle did not show a rotational motion around the longitudinal axis at the $8 \mathrm{~m}$ concrete barrier, it is still deflected upwards due to the impact. The vehicle is redirected into the road after the impact with a run-out angle of $23^{\circ}$, which corresponds 
to the positioning angle of the barrier in the lay-by. The change of velocity to $22 \mathrm{~km} / \mathrm{h}$ is much lower compared to that with the $4 \mathrm{~m}$ concrete barrier. Thus the vehicle would collide with the left tunnel wall at higher collision speed of approximately $78 \mathrm{~km} / \mathrm{h}$. When impacting the $8 \mathrm{~m}$ concrete barrier, the vehicle remains upright with a high pitching angle and only marginal rolling is observed.

The damage pattern of the vehicle for the impact against the Alpina F1-50 showed intrusions into the passenger compartment. Thus, injuries to the lower extremities can be expected in real accidents [53-55]. No intrusions in the test with the Alpina <prototype> were observed.

The impact severity level " $\mathrm{B}$ " requires an $\mathrm{ASI}<=1.4$ and a THIV $<=33 \mathrm{~km} / \mathrm{h}$ [30]. Both thresholds were exceeded at the impact onto the $4 \mathrm{~m}$ concrete element. Even the impact severity level "C" with an ASI limit lower or equal to 1.9 cannot be achieved. The values of ASI and THIV were 2.9 and $53 \mathrm{~km} / \mathrm{h}$ respectively. The used concrete barrier, when used as certified RRS according to EN1317 has an ASI of 1.4 [40]. The ASI for other comparable concrete RRS with a containment level $\mathrm{H} 2$ and a working width W5 used in Austria ranges of between 1.03 and 1.44 [40]. No information is given to the THIV. If the two criteria ASI and THIV are considered alone, the $4 \mathrm{~m}$ concrete barrier is far beyond the average values of certified RRS and does not fulfill the EN 1317-2 [30] requirements. An impact against an unprotected tunnel lay-by end-wall, however, would result in higher values for the ASI ranging from 3.32 to 4.05 (average ASI: 3.67) depending on the impact angle [2] and a higher risk sustaining severe injuries. The THIV ranges from $67.49 \mathrm{~km} / \mathrm{h}$ to $74.72 \mathrm{~km} / \mathrm{h}$ [2]

At the impact with the $8 \mathrm{~m}$ concrete barrier, the impact severity is of a reasonably lower level compared to the $4 \mathrm{~m}$ concrete barrier. The ASI is calculated as 1.6 and the THIV is $30 \mathrm{~km} / \mathrm{h}$, resulting in an impact severity class beyond level " $\mathrm{B}$ " but below the maximum limit of EN 1317-2 [30]. ASI and THIV tend to decrease with a decreasing impact angle. The certified RRS with this concrete barrier length has an ASI of 1.37 [40]. Corresponding values for ASI and THIV of further RRS were mentioned in the earlier paragraph.

For the crash cushion Alpina F1-50 the ASI with 3.3 is far above the limit of 1.4 and the THIV with $74 \mathrm{~km} / \mathrm{h}$ is far above the limit of $44 \mathrm{~km} / \mathrm{h}$ for frontal impact configurations with the crash cushions defined in EN 1317-3 [47]. Although the crash cushion Alpina <prototype > showed better results compared to the type Alpina F1-50, the injury criteria of EN 1317-3 [47] are not met. The ASI (1.8) and THIV $(57 \mathrm{~km} / \mathrm{h})$ are much better compared to the type Alpina F1-50 but still above the limit of 1.4 and $44 \mathrm{~km} / \mathrm{h}$ respectively. The ASI for 22 crash cushions used in Austria ranges from 0.79 to 1.4 [40]. The corresponding values of THIV is not published.

In Austria the impact severity level " $\mathrm{B}$ " with a maximum ASI of 1.4 and a maximum THIV of $44 \mathrm{~km} / \mathrm{h}$ is required in the regulation RVS 09.01.25 [45] (tunnel portals) and in RVS 09.01.24 [44] (tunnel lay-bys) to install crash cushions. No requirements to a single concrete barrier are defined.

Having in mind the necessary installation space of the individual safety measures, it is clear that the values for ASI and THIV decrease with increasing space (Figure 12). The ASI is reduced from 2.9 for the $4 \mathrm{~m}$ concrete barrier to 1.6 for the $8 \mathrm{~m}$ concrete barrier. The THIV is reduced from $53 \mathrm{~km} / \mathrm{h}$ to almost $30 \mathrm{~km} / \mathrm{h}$. Similar results are observed for the crash cushions. The ASI is reduced from 3.3 for the crash cushion Alpina F1-50 to 1.8 for the Alpina <prototype >. The THIV is reduced from $74 \mathrm{~km} / \mathrm{h}$ to $58 \mathrm{~km} / \mathrm{h}$. Although the values decrease with increasing length of the safety measure the minimum length of the tunnel lay-by must not be undercut.

The extent to which ASI and THIV pose a specific risk of injury to an occupant is indicated in Tables 7 and 8. Risk curves of Gabauer and Gabler [56] are used to assess the injury risk. The injury risk curves are based on the Abbreviated Injury Severity (AIS) and were calculated for ASI and THIV. The injury thresholds could be distinguished between the maximum AIS of 2 or greater (MAIS 2+) and 3 (MAIS 3+). Furthermore, the risk curves were generated for unbelted (airbag-only restraint) and belted occupants (belted and airbag restraint). 


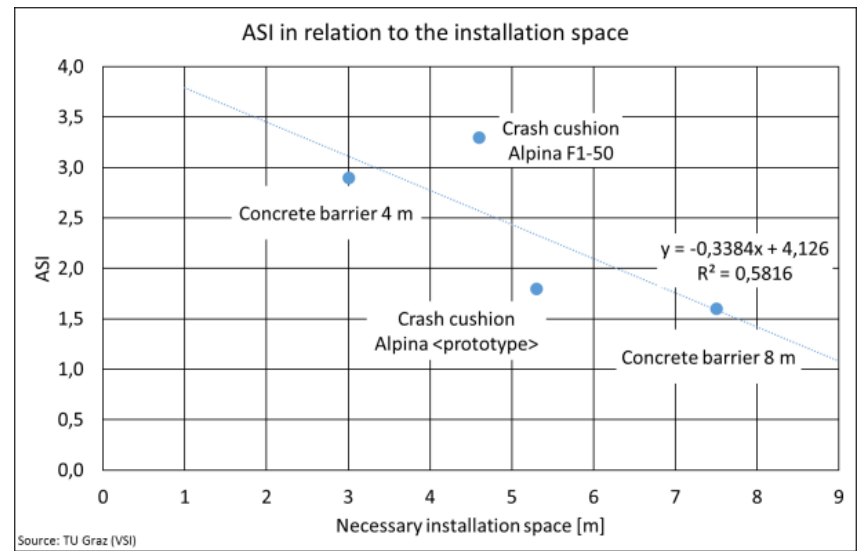

(a)

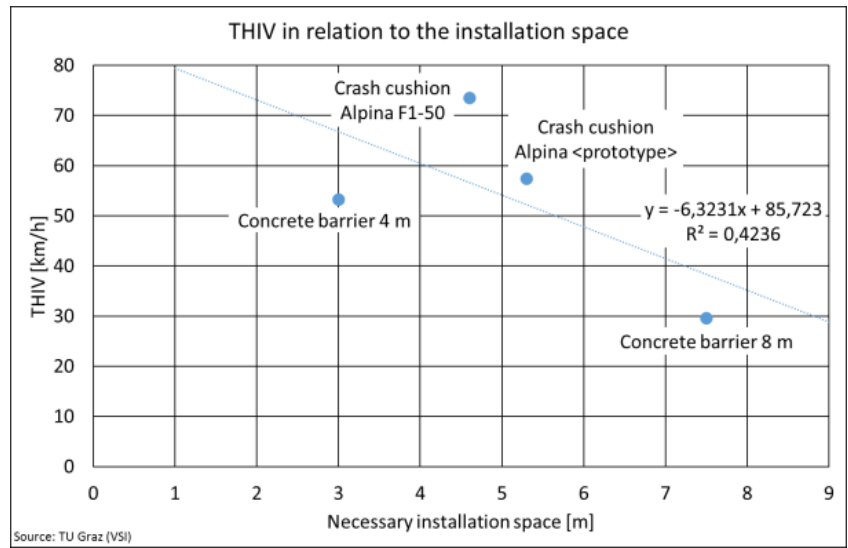

(b)

Figure 12. Relation between necessary installation space of the specific safety measure and ASI (a) and THIV (b). It can be noted that ASI and THIV are reduced with increasing installation space.

Table 7. Corresponding risk of MAIS 2+ and MAIS 3+ [56] injuries of unbelted and belted occupants related to the ASI of the different safety measur.es.

\begin{tabular}{cccccc}
\hline & \multicolumn{2}{c}{ MAIS 2+ } & \multicolumn{2}{c}{ MAIS 3+ } \\
\hline & ASI & Unbelted & Belted & Unbelted & Belted \\
\hline Unprotected wall [2] & 3.7 & $100 \%$ & $98 \%$ & $100 \%$ & $85 \%$ \\
Concrete barrier 4 m & 2.9 & $99 \%$ & $91 \%$ & $97 \%$ & $60 \%$ \\
Concrete barrier 8 m & 1.8 & $84 \%$ & $56 \%$ & $63 \%$ & $21 \%$ \\
Crash cushion Alpina F1-50 & 3.3 & $100 \%$ & $96 \%$ & $99 \%$ & $75 \%$ \\
Crash cushion Alpina <prototype> & 1.6 & $75 \%$ & $46 \%$ & $48 \%$ & $15 \%$ \\
\hline
\end{tabular}

Table 8. Corresponding risk of MAIS 2+ and MAIS 3+ [56] injuries of unbelted and belted occupants related to the THIV of the different safety measur.es.

\begin{tabular}{cccccc}
\hline & & \multicolumn{2}{c}{ MAIS 2+ } & \multicolumn{2}{c}{ MAIS 3+ } \\
& THIV & Unbelted & Belted & UNBELTED & belted \\
\hline Unprotected wall [2] & $56 \mathrm{~km} / \mathrm{h}$ & $97 \%$ & $73 \%$ & $99 \%$ & $38 \%$ \\
Concrete barrier 4 m & $53 \mathrm{~km} / \mathrm{h}$ & $96 \%$ & $69 \%$ & $97 \%$ & $32 \%$ \\
Concrete barrier 8 m & $30 \mathrm{~km} / \mathrm{h}$ & $19 \%$ & $18 \%$ & $1 \%$ & $7 \%$ \\
Crash cushion Alpina F1-50 & $74 \mathrm{~km} / \mathrm{h}$ & $100 \%$ & $94 \%$ & $100 \%$ & $78 \%$ \\
Crash cushion Alpina <prototype $>$ & $57 \mathrm{~km} / \mathrm{h}$ & $98 \%$ & $77 \%$ & $99 \%$ & $42 \%$ \\
\hline
\end{tabular}

The collision against an unprotected end-wall of a tunnel lay-by data provided by Kunc et al. [2] were used as a reference. Nearly all of the safety measures indicate a lower risk of injury for the ASI injury risk curves (Table 7). The crash cushion Alpina F1-50 and the $4 \mathrm{~m}$ concrete barrier do not show a much better protection compared to an unprotected wall. However, MAIS 3+ injuries for belted occupants are a little lower for these two safety measures. It is clear that belted occupants have a lower risk of being injured. Similar findings can be observed for the THIV injury risk curves (Table 8).

Even if ASI and THIV were not be used as the main assessment criteria, in collisions with a concrete barrier the vehicle will be redirected into the road lane which is considered to be critical. The concrete barrier was rotated around the longitudinal axis until the top of the barrier contacted the end-wall of the tunnel lay-by. This rotation supports the upwards deflection of the vehicle. If this effect can be prevented, the vehicle might not lift up to such a great extent and the vehicle rotation after the impact might also be prevented. The redirection of the vehicle into the road lane, however, cannot be prevented with an angled concrete barrier. For the crash cushions only a slight yaw rotation of the vehicle is observed 
from the top view camera. The center line of the vehicle equals the center line of the crash cushion at the impact i.e., without an offset. Thus, the vehicle would rotate much more when only a small part of the vehicle's front impacts the crash cushion. A post-crash motion into the road lane is expected. Following the test configurations of the EN 1317-3 [47] a further frontal impact with an angle of $0^{\circ}$ is mandatory for a CE conformity. In the course of this test the vehicle should hit the crash cushion with a vehicle offset of $25 \%$ from the center line of the crash cushion. In the case of the Alpina F1-50 or the Alpina <prototype > crash cushion the vehicle would still hit with a full overlap. The worst case, however, would be an offset impact in which only $25 \%$ of the vehicle hits the crash cushion but unfortunately tests of this kind are not foreseen in EN 1317-3 [47].

The impact was defined at the mid-point of the concrete barrier with a vehicle corresponding to the TB11 weight requirements of EN 1317-1 [46] to evaluate if the concrete barrier would be penetrated. No damage of the latter i.e., penetration is observed. The vehicle kerb weight of all newly registered passenger cars in Germany has been increasing in recent years and reached an average of approximately $1515 \mathrm{~kg}$ in 2018 [57]. An analysis of 110 different vehicles tested at Euro NCAP revealed a similar picture. The average mass of currently produced and tested vehicles is $1541 \mathrm{~kg}(\mathrm{SD}=364)$. Roughly $90 \%$ of the vehicles have a weight of up to $2000 \mathrm{~kg}$. $10 \%$ of the vehicles analysed exceed $2000 \mathrm{~kg}$. The small vehicle used in EN 1317- [46] to assess the degree of protection for the occupants of small vehicles in the event of a crash of an impact does not permit conclusions to be drawn when a vehicle of greater mass impacts the barrier. The risk of penetrating the barrier does increase with increasing vehicle weight, however, and an impact into the end-wall of the lay-by is considered to be more likely.

A critical location is at the edge of the lay-by end-wall. If the vehicle impacts the barrier with a small overlap i.e., only a small part of the vehicle front width impacts the barrier the risk of intrusions into the passenger compartment is relatively high and this will involve severe injuries for the occupants [58].

In the crash cushion tests artefacts such as the gap between the crash cushion and the end-wall of the lay-by, the offset impact of the vehicle, the lack of information on performance in the event of a vehicle impacting the side of the crash cushion were identified. The probability that a vehicle will move between the gap of the crash cushion back-up and the edge of the tunnel lay-by is considered to be very low. However, the damage to the vehicle would be massive and the risk of sustaining severe injury would be disproportionately high. Thus, it is proposed to position the complete crash cushion as close as possible to the lay-by end-wall. The resulting missing space behind the crash cushion that this will entail, however, will need to be analysed with respect to influence on the performance. Further, a rectangular shaped back-up instead of a triangular shaped back-up might reduce the probability of hitting the edge of the lay-by in case of a run-off road accident.

In addition, there is a critical point at the transition of the cushion bag to the concrete back-up. No performance information is available for the case of a vehicle impact to the side of the crash cushion. The probability of hitting this specific point, however, is considered to be low.

While infrastructure measures are to be used for mitigating injury consequences in the event of an impact, collision avoidance is nevertheless a more important issue. Rumble strips are under considerations in some countries as a collision avoidance measure [41]. In the European Union, however, lane supporting systems will become mandatory for new registered vehicles of categories M1 and N1 [59]. It is expected as a result that run-off-road accidents will be reduced $[60,61]$.

\section{Limitations}

A test set-up a frontal impact with a full overlap of the vehicle was used. In real accident impact conditions this impact configuration might not be present. For the certification of a crash cushion according to EN 1317-3 [47] a test with an vehicle offset is mandatory.The width of the crash cushions used, however, is so large that the front of the 
vehicle will still have a complete overlap. Thus, the testing of crash cushions with a small vehicle overlap would be of interest, i.e., the vehicle impacts the crash cushion with a small overlap (Figure 13a).

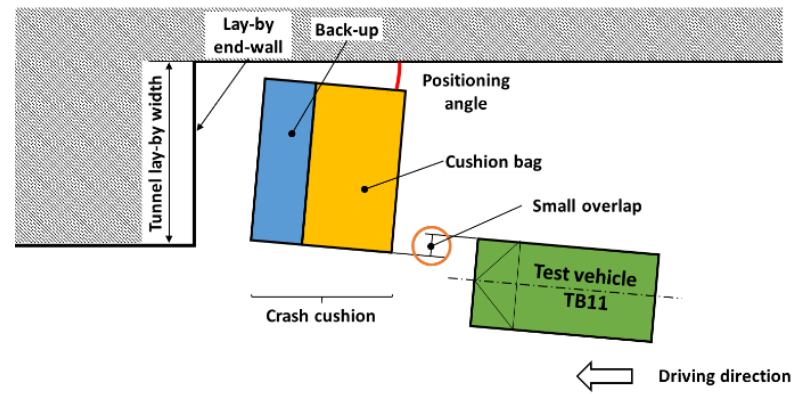

(a)

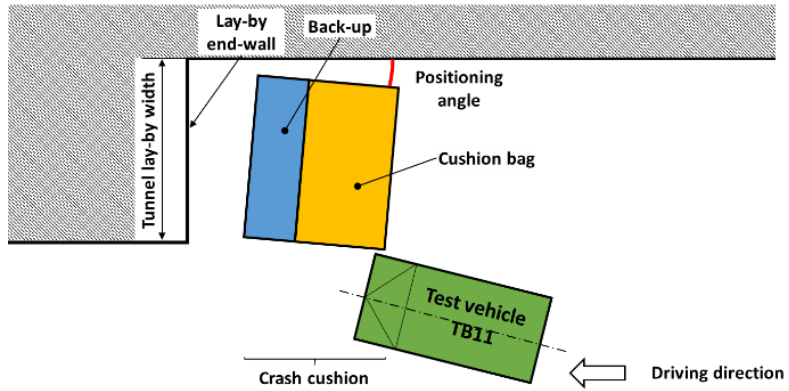

(b)

Figure 13. Crash configurations for crash cushion. (a): Small overlap of the vehicle; (b): Impact into the transition of the cushion bag to the concrete back-up.

To certify redirective crash cushions according to EN 1317-3 [47] a side impact is required. Although the analysed crash cushions are non redirective, assessing the performance of impacts on the side of the crash cushion would be of interest (Figure 13b). The transition from the cushion bag to the concrete back-up in particular, is assumed to represent a higher risk.

Similar to crash cushions the concrete barriers were tested with a full vehicle overlap. Tests with a small overlap would be of interest (Figure 14a). The edge between the concrete barrier and the side wall of the tunnel lay-by is identified as a further critical impact location (Figure 14b).

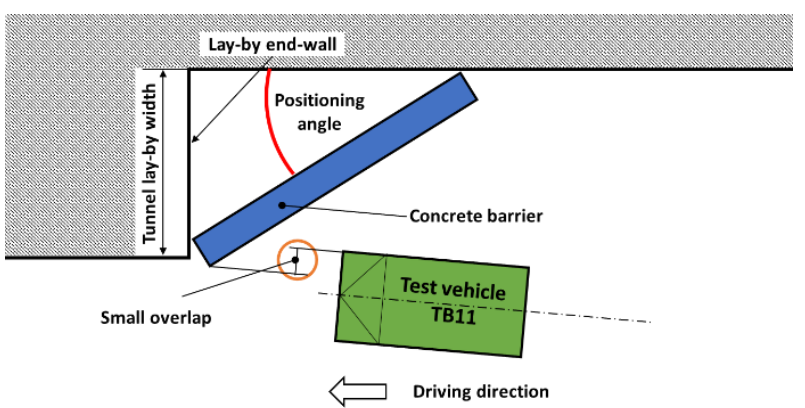

(a)

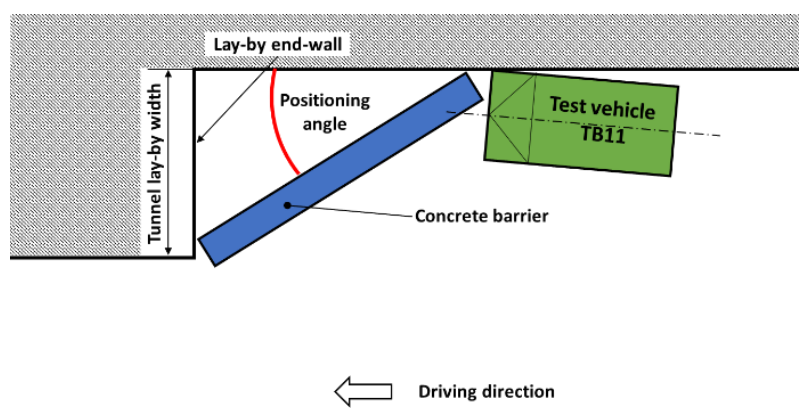

(b)

Figure 14. Crash configurations for angled concrete barriers. (a): Small overlap of the vehicle; (b): Impact into the transition of the concrete barrier and tunnel lay-by side wall.

During the tests a rotation of the concrete barrier around the longitudinal axis was observed until the top of the barrier contacted the end-wall of the tunnel lay-by. To which extent a fully fixed barrier, i.e., rotation around the longitudinal axis is constrained, influences the values of ASI and THIV is not known.

The vehicles used for the tests must be production models representative of current vehicle population, having characteristics and dimensions within the vehicle specifications defined in EN 1317-1 [46]. The vehicles used are generally very old, but nevertheless fulfil the requirements for the tests. They are largely lacking in sophisticated occupant protection devices such as airbags, pretensioning equipment, etc. In view of this, it is recommended to run the tests against the crash cushions using newer vehicles and protective devices.

The vehicles used for the tests have a kerb mass of $825+/-40 \mathrm{~kg}$. The average mass of a new registered passenger car in Germany increased from $1426 \mathrm{~kg}$ to $1515 \mathrm{~kg}$ in the period 
from 2005 and 2018 [57]. An analysis of the minimum weight of passenger cars between 2001 and 2017 showed an increase of $20 \%$ from $1000 \mathrm{~kg}$ to $1200 \mathrm{~kg}$ [62].

\section{Conclusions}

Taking the severity indices ASI and THIV into consideration in determining how well one of the four protective measures performs, it can be concluded that none of them fulfils the requirements of EN 1317-2 [30] or EN 1317-3 [47] as used in this study.

The crash cushion Alpina F1-50 is not designed to cope with high speed events. The values for the crash cushion Alpina F1-50 are thus far above the limits. The crash cushion Alpina <prototype > had a much better performance compared to the type Alpina F150, but still does not meet the limits for ASI and THIV. The <prototype $>$ crash cushion has now been fully developed (referenced to as Alpina F1-80) and it is expected that the crash cushion will perform better under the defined conditions of this study. The best performance in terms of these two indices was that of the $8 \mathrm{~m}$ concrete barrier. ASI and THIV both decrease with a decreasing impact angle. However, the vehicle will be redirected into the road lane and impacting the tunnel wall on the left side with a high speed and the occupants are at a high risk of sustaining severe injuries.

From a priority perspective according to ASI and THIV the following recommendations can be made in the order given below:

1. Crash cushion Alpina <prototype $>$ (not designed for this speed limit)

2. $8 \mathrm{~m}$ concrete barrier

3. Crash cushion Alpina F1-50 (not designed for this speed limit)

4. $4 \mathrm{~m}$ concrete barrier (should nothing else be available, which can be used to protect vehicle occupants on crash impacts)

Even though an increasing installation space is beneficial for the indices ASI and THIV the length of a lay-by in Austria should not be shorter than $40 \mathrm{~m}$ without the necessary space of a protective safety measure. In existing tunnels in particular the possibilities for positioning specific safety measures are limited.

Apart from the assessment criteria used further parameters such as the on-site requirements (e.g. available space, bend radius, etc.), maintenance, operational conditions, etc. should also be taken into consideration.

Author Contributions: Conceptualization: E.T.; Methodology: E.T., S.F.H.; Formal analysis: E.T., S.F.H., G.G.; Writing—original draft preparation: E.T.; Writing-review and editing: G.G., W.S.; Supervision: H.S.; Project administration: E.T.; Funding acquisition: E.T., W.S. All authors have read and agreed to the published version of the manuscript.

Funding: This research was funded by the Austrian Research Promotion Agency (FFG) "Mobilität der Zukunft, 5. Ausschreibung Verkehrsinfrastrukturforschung" tender grant number 854613.

Institutional Review Board Statement: Not applicable.

Informed Consent Statement: Not applicable.

Data Availability Statement: No report on further data.

Conflicts of Interest: The authors declare no conflict of interest.

\section{References}

1. European Parliament; Council of the European Union. Directive 2004/54/ec of the European Parliament and of the Council on Minimum Safety Requirements for Tunnels in the Trans.-European Road Network; 2004/54/EC. European Parliament, Council of the European Union, 2004.

2. Kunc, R.; Omerović, S.; Ambrož, M.; Prebil, I. Comparative study of European tunnel emergency-stop-area-wall protection measures. Acc. Anal. Prevent. 2014, 63, 9-21. [CrossRef]

3. Strnad, B.; Schmied, S. Bericht über Brände und Unfälle in Tunnelanlagen: Bericht gemäß § 3 Abs. 8 STSG Beziehungsweise; EU-Direktive 2004/54/EG; Bundesministerium für Verkehr, Innvoation und Technologie: Wien, Austria, 2018. 
4. Ma, Z.-L.; Shao, C.-F.; Zhang, C.-F. Characteristics of traffic accidents in Chinese freeway tunnels. Tunnell. Undergr. Space Technol. 2009, 24, 350-355. [CrossRef]

5. Mashimo, H. State of the road tunnel safety technology in Japan. Tunnell. Undergr. Space Technol. 2002, 17, 145-152. [CrossRef]

6. Amundsen, F.; Engebretsen, A. Studies on Norwegian Road Tunnels II an Analysis on Traffic Accidents in Road Tunnels 2001-2006; Roads and Traffic Department: Oslo, Norway, 2009.

7. Kirkland, C.J. The fire in the Channel Tunnel. Tunnell. Undergr. Space Technol. 2002, 17, 129-132. [CrossRef]

8. Robatsch, K.; Nussbaumer, C. Verkehrssicherheitsvergleich Von Tunneln Mit Gegenverkehr Und Richtungsverkehr in Österreich; Strasse und Autobahn: Bonn, Germany, 2004.

9. Amundsen, F.H.; Ranes, G. Studies on traffic accidents in Norwegian road tunnels. Tunnell. Undergr. Space Technol. 2002, 15, 3-11. [CrossRef]

10. Brandt, R.; Schubert, N.; Høj, N. On Risk Analysis of Complex Road-Tunnel Systems. In Proceedings of the 6th International Conference Tunnel Safety and Ventilation: Sicherheit und Belüftung von Tunnelanlagen, Graz, Austria, $23-25$ April 2012.

11. Yeung, J.S.; Wong, Y.D. Road traffic accidents in Singapore expressway tunnels. Tunnell. Undergr. Space Technol. 2013, 38, 534-541. [CrossRef]

12. Guo, W.; Pan, X.; Deng, Q.; Fu, Z. Traffic Accidents' Distribution in the Highway Tunnels of Mountainous Areas and Preventive Measures. In ICTE 2013; Peng, Q., Wang, K.C.P., Eds.; American Society of Civil Engineers: Reston, VA, USA, 2013 ; pp. 507-513.

13. Lu, L.; Lu, J.; Xing, Y.; Wang, C.; Pan, F. Statistical Analysis of Traffic Accidents in Shanghai River Crossing Tunnels and Safety Countermeasures. Discrete Dynam. Nat. Soc. 2014, 2014, 1-7. [CrossRef]

14. Sun, H.; Wang, Q.; Zhang, P.; Zhong, Y.; Yue, X. Spatialtemporal Characteristics of Tunnel Traffic Accidents in China from 2001 to Present. Adv. Civil. Eng. 2019, 2019, 1-12. [CrossRef]

15. Statistik Austria. Information zur Statistik der Straßenverkehrsunfälle mit Personenschaden ab dem Berichtsjahr 2012; Wien, Austria, 2017. Available online: http://www.statistik.at/web_de/static/information_zur_statistik_der_strassenverkehrsunfaelle_mit_ personenschaden_065391.pdf (accessed on 20 May 2021).

16. BMVIT. Österreichisches Verkehrssicherheitsprogramm 2011 bis 2020, 2nd ed.; Wien, Austria, 2016; Available online: https:// www.bmk.gv.at/themen/verkehr/strasse/verkehrssicherheit/publikationen/programme_berichte/vsp2020.html (accessed on 20 May 2021).

17. ASFINAG. Verkehrssicherheitsprogramm. 2010. Available online: https://verkehrssicherheit.asfinag.at/media/1762/de_ verkehrssicherheitsprogramm-2020.pdf (accessed on 20 May 2021).

18. Zumsteg, F.; Steinemann, U.; Eisenlohr, M. On the Road to Safer Tunnels. In Proceedings of the 8th International Conference Tunnel Safety and Ventilation: New developments in tunnel safety, Graz, Austria, 25-26 April 2016.

19. Leitner, A. The fire catastrophe in the Tauern Tunnel: Experience and conclusions for the Austrian guidelines. Tunnell. Undergr. Space Technol. 2001, 16, 217-223. [CrossRef]

20. Haack, A. Current safety issues in traffic tunnels. Tunnell. Undergr. Space Technol. 2002, 17, 117-127. [CrossRef]

21. Nævestad, T.-O.; Meyer, S. A survey of vehicle fires in Norwegian road tunnels 2008-2011. Tunnell. Undergr. Space Technol. 2014, 41, 104-112. [CrossRef]

22. Caliendo, C.; Ciambelli, P.; de Guglielmo, T.-O.; Meo, M.G.; Russo, P. Numerical simulation of different HGV fire scenarios in curved bi-directional road tunnels and safety evaluation. Tunnell. Undergr. Space Technol. 2012, 31, 33-50. [CrossRef]

23. Caliendo, C.; Ciambelli, P.; de Guglielmo, M.L.; Meo, M.G.; Russo, P. Simulation of fire scenarios due to different vehicle types with and without traffic in a bi-directional road tunnel. Tunnell. Undergr. Space Technol. 2013, 37, 22-36. [CrossRef]

24. Barbato, L.; Cascetta, P.; Musto, M.; Rotondo, M. Fire safety investigation for road tunnel ventilation systems-An overview. Tunnell. Undergr. Space Technol. 2014, 43, 253-265. [CrossRef]

25. Chen, F.; Chien, S.-W.; Lee, Y.-P.; Lin, C.-F.; Sie, H.-R. The Integrated Strategies for Fire Safety of Long Road Tunnels in Taiwan. Proc. Eng. 2013, 62, 36-45. [CrossRef]

26. Gehandler, J. Road tunnel fire safety and risk: A review. Fire Sci. Rev. 2015, 4, 215. [CrossRef]

27. Vidmar, P. Novel Approach in Tunnel Safety Assessment. In Accident Analysis and Prevention; Darçın, M., Ed.; IntechOpen: London, UK, 2020.

28. Kunc, R.; Omerović, S.; Ambrož, M.; Prebil, I. How to Protect the Tunnel SOS Niche Wall in the Event of Vehicle Impact. Transport. Res. Proc. 2016, 14, 1305-1314. [CrossRef]

29. Gabauer, D.; Thompson, R. Correlation of Vehicle and Roadside Crash Test Injury Criteria. In Proceedings of the The 19th ESV Conference, National Highway Traffic Safety Administration (NHTSA), Washington, DC, USA, 6-9 June 2005.

30. Comité Européen De Normalisation. EN 1317-2: Road Restraint Systems_Part. 2: Performance Classes, Impact Test. Acceptance Criteria and Test. Methods for Safety Barriers Including Vehicle Parapets 13.200. 2011. Available online: https://infostore.saiglobal. com/preview /98698023876.pdf?sku=865361_SAIG_NSAI_NSAI_2058198 (accessed on 20 May 2021).

31. Shojaati, M. Correlation between injury risk and impact severity index ASI. In Proceedings of the 3rd Swiss Transport Research Conference, Monte Veritá, Ascona, 19-21 March 2003.

32. Anghileri, M.; Luminari, M.; Williams, G. Analysis of Test. Data from European Laboratories. Project ROBUST Deliverable D.2.1. 2005. Available online: https://www.vegvesen.no/s/robust/Testing_Prosedure/D_2_1_6.pdf (accessed on 20 May 2021). 
33. Chell, J.; Brandani, C.E.; Fraschetti, S.; Chakraverty, J.; Camomilla, V. Limitations of the European barrier crash testing regulation relating to occupant safety. Acc. Anal. Prevent. 2019, 133, 105239. [CrossRef]

34. Sturt, R.; Fell, C. The relationship of injury risk to accident severity in impacts with roadside barriers. Int. J. Crashworthines 2009, 14, 165-172. [CrossRef]

35. Borovinšek, M.; Vesenjak, M.; Ulbin, M.; Ren, Z. Simulation of crash tests for high containment levels of road safety barriers. Eng. Fail. Anal. 2017, 14, 1711-1718. [CrossRef]

36. Budzynski, M.; Jamroz, K.; Wilde, K.; Witkowski, W.; Jelinski, L.; Bruski, D. The role of numerical tests in assessing road restraint system functionality. Eur. Transp. Res. Rev. 2020, 12, 4209. [CrossRef]

37. Klootwijk, C.; Hoogvelt, R.H. Sensitivity of car with guardrail impacts with a multibody simulation tool. In Proceedings of the 2nd International Conference on ESAR Expert Symposium on Accident Research, ESAR, Hanover, Germany, 1-2 September 2006; pp. 194-196.

38. Pachocki, L.; Bruski, D. Modeling, simulation, and validation of a TB41 crash test of the H2/W5/B concrete vehicle restraint system. Archiv. Civ. Mech. Eng. 2020, 20, 1. [CrossRef]

39. Ren, Z.; Vesenjak, M. Computational and experimental crash analysis of the road safety barrier. Eng. Fail. Anal. 2005, 12, 963-973. [CrossRef]

40. Federal Ministry Republic of Austria. Climate Action, Environment, Energy, Mobility, Innovation and Technology, Road restraint systems. Available online: www.bmk.gv.at/themen/verkehr/strasse/infrastruktur/verkehrstechnik/rueckhalt.html (accessed on 20 May 2021).

41. Technical Committee C3.3 Road Tunnels Operations, Lay Bys and Protection Against Lateral Obstacles-Current Practices in Europe. La Défense cedex, France. 2016. Available online: https://www.piarc.org/en/order-library/25104-en-Lay\%20bys\%20 and\%20protection\%20against \%20lateral\%20obstacles\%20-\%20Current\%20practices\%20in\%20Europe (accessed on 20 May 2021).

42. Alpina Crash Cushion. Available online: www.alpina.at/alpina-expandiert-nach-irland-alpina-anpralldampfer-im-dublin-porttunnel-aufgestellt/ (accessed on 20 May 2021).

43. ASFINAG. Serviceheft. 2016. Available online: Haltau.at/images/download/ASFINAG\%20Serviceheft\%202016.pdf (accessed on 20 May 2021).

44. Forschungsgesellschaft Straße-Schiene-Verkehr, RVS 09.01.24. Bauliche Anlagen für Betrieb und Sicherheit, Wien., Österreichische Forschungsgesellschaft Straße-Schiene-Verkehr; FSV (C) 2016-2021: Wien, Austria, 2014.

45. Forschungsgesellschaft Straße-Schiene-Verkehr, RVS 09.01.25. Vorportalbereich, Wien., Österreichische Forschungsgesellschaft Straße-Schiene-Verkehr; FSV (C) 2016-2021: Wien, Austria, 2015.

46. Comité Européen De Normalisation. EN 1317-1: Road Restraint Systems_Part. 1: Terminology and General Criteria for Test. Methods 13.200. 2010. Available online: http:/ / www.extrudakerb.com/pdf/EN1317-1.pdf (accessed on 20 May 2021).

47. Comité Européen De Normalisation. EN 1317-3: Road Restraint Systems_Part. 3: Performance Classes, Impact Test. Acceptance Criteria and Test. Methods for Crash Cushions 13.200. 2011. Available online: http:/ / www.extrudakerb.com/pdf/BS\%20EN\%2013 17-3\%202010.pdf (accessed on 20 May 2021).

48. Tomasch, E.; Steffan, H. ZEDATU—Zentrale Datenbank tödlicher Unfälle in Österreich-A Central Database of Fatalities in Austria. In Proceedings of the 2nd International Conference on ESAR “Expert Symposium on Accident Research”, ESAR, Hanover, Germany, 1-2 September 2006.

49. Tomasch, E.; Steffan, H.; Darok, M. Retrospective accident investigation using information from court; Transport. Research Arena Europe: Ljubljana, Slovenia, 2008.

50. Hoschopf, H.; Tomasch, E. Single Vehicle Accidents, Incidence and Avoidance. In Proceedings of the 3rd International Conference on ESAR “Expert Symposium on Accident Research”, Hanover, Germany, 5-6 September 2008.

51. REBLOC. Product Information Concrete Barriers. Available online: www.rebloc.com/en/eco-permanent/ (accessed on 20 May 2021).

52. Alpina Sitec Produktinformation F1-50. Available online: www.sitec.co.at/assets/files/Produktionformation\%20F1-50.pdf (accessed on 20 May 2021).

53. Austin, R.A. Lower extremity injuries and intrusion in frontal crashes. Acc. Reconstruc. J. 2013, 23, 11-17.

54. Austin, R. Lower Extremity Injuries and Intrusion in Frontal Crashes; Report No: DOT HS 811 578; National Highway Traffic Safety Administration: Washington, DC, USA, 2012.

55. Zhang, R.; Reichert, R.; Kan, S.; Cao, L. Evaluation of driver lower extremity injuries in 16 oblique crashes with THOR. Int. J. Crashworthines 2016, 21, 120-134. [CrossRef]

56. Gabauer, D.J.; Gabler, H.C. Comparison of roadside crash injury metrics using event data recorders. Acc. Anal. Prevent. 2008, 40, 548-558. [CrossRef] [PubMed]

57. Kraftfahrt-Bundesamt. Durchschnittliches Leergewicht von neu zugelassenen Personenkraftwagen in Deutschland in den Jahren 2005 bis 2018. 2019. Available online: https://de.statista.com/statistik/daten/studie/12944/umfrage/entwicklung-des-leergewichtsvon-neuwagen/ (accessed on 20 May 2021).

58. Larrson, B.; Bakker, J. Small Overlap Frontal Impact-Experience and Proposal for a Future Approach. In Proceedings of the 24th ESV Conference Proceedings, National Highway Traffic Safety Administration (NHTSA), Gothenburg, Sweden, 8-11 May 2015. 
59. Official Journal of the European Union. Regulation (eu) 2019/2144 of the European Parliament and of the Council of 27 November 2019 On Type-Approval Requirements for Motor Vehicles and Their Trailers, and Systems, Components and Separate Technical Units Intended for Such Vehicles, as Regards Their General Safety and the Protection of Vehicle Occupants and Vulnerable Road Users. REGULATION (EU) 2019/2144. 2019. Available online: https:/ / eur-lex.europa.eu/eli/reg/2019/2144/oj (accessed on 20 May 2021).

60. Cafiso, S.; Pappalardo, G. Safety effectiveness and performance of lane support systems for driving assistance and automationExperimental test and logistic regression for rare events. Acc. Anal. Prevent. 2020, 148, 105791. [CrossRef]

61. Pappalardo, G.; Cafiso, S.; Di Graziano, A.; Severino, A. Decision Tree Method to Analyze the Performance of Lane Support Systems. Sustainability 2021, 13, 846. [CrossRef]

62. International Council on Clean Transportation Europe. Europen Vehicle Market Statistics: Pocketbook 2019/20; Berlin, Germany, 2019. Available online: https://theicct.org/sites/default/files/publications/European_vehicle_market_statistics_20192020_2019121 6.pdf (accessed on 20 May 2021). 